\title{
From Coordinated Campaigns to Watertight Compartments: Diseased Sheep and their Investigation in Britain, c.1880-1920
}

\section{Abigail Woods}

In the spring of 1881, diseased sheep in various parts of Scotland received a visit from a $\mathrm{Mr}$ Andrew Brotherston, taxidermist, gardener and plant collector from the border town of Kelso. He was accompanied by Professor Williams, principal of the New Edinburgh Veterinary College, Dr David Hamilton, an Edinburgh University pathologist, and Dr A.P. Aitken, a medical trained agricultural chemist. Assisted by local farmers, shepherds, landowners and a geologist, the men hunted down and tried to make sense of sheep suffering from the seasonally prevalent and geographically localized diseases known to farmers as 'braxy' or 'sickness', and 'louping ill' or 'trembling'.

Williams investigated the reported symptoms of louping ill, which ranged from swollen joints and navels to staggering, trembling, wasting, uncoordinated leaping or 'louping', and paralysis. He also conducted post-mortem examinations which identified pathological changes to sheep spinal cords. Hypothesizing that this tissue might contain a 'germ poison', Drs Hamilton and Aitken used mutton broth to culture germs from it, and from the blood of a diseased sheep they killed for the purpose. Initially they were excited to find bacteria resembling those of 'chicken cholera', the recent subject of Louis Pasteur's first vaccine, but these soon died out. Unable to locate any additional diseased sheep, they made no further progress. Meanwhile, Brotherston examined the physical features and vegetation of sheep pastures. He suspected that disease might be caused by ergot fungus, which he found on 23 types

A. Woods et al., Animals and the Shaping of Modern Medicine,

Medicine and Biomedical Sciences in Modern History, https://doi.org/10.1007/978-3-319-64337-3_3 
of grass, but when they were fed to sheep, nothing happened. The men also explored popular hypotheses implicating climate, altitude, geology, soil type and blood-sucking ticks that inhabited the herbage, but they reached no definitive conclusions. The enquiry ended in 1884 with the rather generic recommendations that to improve sheep health, farmers should provide additional fodder, improve the fertility of pastures and remove rank vegetation that provided cover for ticks. ${ }^{1}$

At the time this was the largest independent investigation into sheep health ever undertaken in Britain. ${ }^{2}$ It fashioned sheep into scientific subjects and reshaped their lived experiences by simultaneously fragmenting them into their bodily constituents and situating them within their wider environments. Setting the scene for a succession of similar enquiries that took place over the next two decades, it was informed by the sheep's tendency to fall ill at particular times and in particular places, and brought a variety of scientific perspectives to bear on them.

Williams' participation is easily attributed to his veterinary professional interest in sick sheep. However, the other participants present something of a puzzle to historians. While Brotherston's efforts to identify plant species and their geographical distribution were typical of amateur botanists of the time, historians have not associated such activities with the promotion of British livestock health. ${ }^{3}$ When attempting to explain medical interest in livestock, authors typically refer to the profession's interest in preventing diseases that spread from animals to humans. ${ }^{4}$ However, there was no indication that braxy or louping ill spread in this way: shepherds had long consumed the meat of 'braxy sheep' without suffering harmful effects. ${ }^{5}$ It was animal health, not human health, that drove these investigations. Sponsored and directed by the prestigious Highland and

\footnotetext{
1 'Proceedings' (1882), 'Second Report' (1883), 'Braxy and Louping Ill' (1884).

${ }^{2}$ The government's 1865-1867 enquiry into cattle plague or rinderpest had looked at whether sheep were susceptible to the disease, but they were not the main focus of investigation. United Kingdom Parliament (1866). The imported, scheduled disease, sheep pox, had also been subjected to publicly funded investigations on its appearance in 1862 . These aimed to determine the efficacy of vaccination. Marson and Simonds (1864).

${ }^{3}$ Allen (1976), Kohler (1976), Cittadino (2009). However, in colonial contexts, investigations into the effects of certain plants on livestock health have been noted. Brown (2007), Clayton (2008).

${ }^{4}$ Cassidy et al. (2017).

${ }^{5}$ The right to carcasses of fallen sheep comprised an 'allowance in kind' for Highland shepherds. They were generally permitted a set number each year for consumption. United Kingdom Parliament (1900).
} 
Agricultural Society (HAS), their history reveals that in late nineteenthcentury Britain, diseased sheep were not perceived as the specifically veterinary problems that historians have assumed them to be. Rather, they appealed to, and forged connections between, experts in human medicine, veterinary medicine and the natural world.

After introducing sheep, and the manner in which they were farmed, the first part of this chapter seeks to explain their positioning at the hub of this eclectic research network. It will document the investigations performed, and how sheep influenced and were affected by them. It will reveal that while sheep played multiple roles within the research network, their investigation was underpinned by farmers' perceptions of them as products of place. On account of this perception, sheep were studied primarily in farmed environments, where they proved capable of making a difference to scientific enquiries. The remainder of the chapter explores how this mode of investigation changed in the early twentieth century, when investigators reconceptualized diseased sheep as hosts and transmitters of infection, decoupled them from their farmed environments, and promoted their investigation in laboratories in the hope of making them more amenable to human control. In the process, medical men and practical farmers became distanced from the scientific study of sheep, sheep lost influence over investigations, and veterinarians sought to capture sheep for themselves. This history therefore demonstrates how sheep first integrated, and then contributed to the disciplinary compartmentalization of experts in their diseases.

The shifting approach to diseased sheep was informed by the institutionalization, disciplinary specialization, and growth of state funding for agricultural research. ${ }^{6}$ These changes are well documented by historians. However, in failing to award equal attention to the earlier mode of research, ${ }^{7}$ and to recognize sheep as key shapers and participants, ${ }^{8}$ authors offer a rather

\footnotetext{
${ }^{6}$ Olby (1991), Vernon (1997), Kraft (2004), Woods (2013).

${ }^{7}$ One of the few accounts of agricultural research in later nineteenth-century Britain is Brassley (1995). This overlooks investigations conducted by agricultural societies, and analyses British research in comparison with that pursued simultaneously in Germany and subsequently in Britain. The conclusion-that British research 'failed'-is not helpful in understanding its significance and pursuit at the time.

${ }^{8}$ In fact very few historians have elected to foreground sheep. They include: Crosby (1972), Ryder (1983), Melville (1994), Butler (2006), Franklin (2007), Ritvo (2010), Woods (2015), Armstrong (2016). Philosopher Vinciane Despret reflects on why ethologists have not found sheep interesting - a question that may have some bearing on why historians have not elected to study them (Despret 2006).
} 
teleological, anthropocentric version of events, which overlooks the fact that sick sheep were once subjects of medicine and natural history as well as veterinary medicine. This point is also overlooked in histories of British medicine and veterinary medicine, which have little to say about diseased sheep in Britain except in regard to the zoonotic disease, anthrax. ${ }^{9}$

In shifting the historical focus from sheep diseases to diseased sheep, this chapter reinstates sheep as actors and brings them from the margins to the centre of enquiry. Like the other chapters in the volume, it relies on the material-semiotic traces they left on the historical record. ${ }^{10}$ These traces document what humans did to sheep in order to enhance their performance as producers of meat, wool, profit and scientific knowledge. They survive in accounts of farming practices, geographies and landscapes; in the disease narratives of farmers and landowners; in reports of investigations performed by diverse scientific experts; and in government reports and statistics. They demonstrate the evolving relationships between sheep, humans and other non-human actors such as the farmed environment, microbes and parasites. ${ }^{11}$ As Mol and Law have demonstrated for Cumbrian sheep during the British 2001 footand-mouth disease epidemic, it is through such relationships that sheep act, and are in turn acted on, with often unintended consequences for all parties. Following these authors, this chapter will reveal the ways in which sheep made a difference to human history, even though they did not control or set out intentionally to change it. ${ }^{12}$ It will also develop new perspectives on the nature of, and relationships between, human medicine, veterinary medicine and the life sciences in Britain c.1900, and reflect, in conclusion, on the implications of these findings both historically and for the present-day agenda known as One Health $(\mathrm{OH}) .{ }^{13}$

\footnotetext{
${ }^{9}$ Accounts of anthrax include: Jones (2010), Stark (2013), Wall (2013). Sheep diseases have, however, been studied in colonial contexts owing to the significance of sheep to their economies. See Brown (2003, 2007), Clayton (2008), Peden (2010). Two important accounts of sheep as participants in other aspects of medicine are Schlich and Schlünder (2009), Kirk and Ramsden (2017).

${ }^{10}$ Haraway (2004), Haraway (2008), Benson (2011), Cassidy et al. (2017).

${ }^{11}$ Just as the exclusion of animals from history is a deliberate choice, so, too, is the elevation of sheep in this chapter. It would be equally possible to centre this history on a different non-human actor, as Chapter 5 does in its history of Echinococcus granulosus, a tapeworm that infected sheep.

${ }^{12}$ Law and Mol (2008).

${ }^{13}$ Zinsstag et al. (2011). See also Chapter 6.
} 


\subsection{Coordinated Campaigns}

In mid-nineteenth-century Britain, mutton and wool prices were buoyant and sheep farming boomed. Much of the agricultural land in Scotland was devoted to this activity, especially on large commercial farms created by landlords' appropriation and enclosure of common land. Two breeds of sheep dominated: Cheviot and Blackface. Originating on the Cheviot Hills that straddled Northumberland and the Scottish borders, Cheviot sheep were perceived as an adaptable, hardy and easily maintained breed that contributed more than any other to the prosperity of Scottish farmers. They produced excellent mutton and a higher grade of wool than the Blackface, and therefore gained in popularity against them, until a series of bad winters around 1860 demonstrated the superior hardiness of Blackface sheep on hills and moorland. Said to possess 'wonderful individuality, no two being exactly alike', the semi-wild Blackface sheep were thought to add beauty to the Scottish landscapes. ${ }^{14}$ They won respect for their stamina, maternal instincts and ability to survive on meagre pasture, which they sought out by digging through winter snowdrifts. They were also renowned for their excellent mutton. Like the Cheviot, they were sometimes crossed with lowland Border Leicester sheep to produce a larger, meatier carcass. Efforts to improve both breeds were under way. Their hill grazing land was also subject to improvement through drainage and the periodic burning of heather, which encouraged the growth of young grasses. ${ }^{15}$

These sheep were left to 'go at large over their walk'. ${ }^{16}$ Having a deep knowledge of their location or 'heaf', they did not wander. Typically they swept down from the hills at dawn to graze-'taking no more off the grass than is required for future growth'-then moved back slowly by evening, having enriched the soil through their manure. ${ }^{17}$ Guided and monitored by shepherds, they lived outdoors all year round, being gathered together at intervals for clipping, branding, chemical treatments to kill parasites, and selection for sale or breeding. While commentators acknowledged the great variability of these practices, they distinguished

\footnotetext{
${ }^{14}$ Usher (1875) p. 8.

${ }^{15}$ Reid and Kemp (1871), Usher (1875), Archibald (1880) pp. 110-22, Hart (1956), Carlyle (1979).

${ }^{16}$ Usher (1875) p. 15.

${ }^{17}$ Reid and Kemp (1871) p. 84.
} 
hill farming from the mixed sheep farming systems that prevailed in Southern England. There, sheep provided not only meat and wool, but also fertility to fields that were rotated annually between fodder, barley, seeds and wheat production. They came from rapidly growing and early maturing lowland breeds which varied by locality and were perceived as gentler and less hardy than the hill breeds. ${ }^{18}$

British sheep production reached its zenith in the 1870s, when the population peaked at around 28 million. Subsequently, the rapid expansion of grain imports from the North American prairies undermined the viability of mixed farming, while imports from Australia, New Zealand and South Africa depressed British mutton and wool prices. Reportedly, Scottish mountain pastures were deteriorating, forcing farmers to reduce sheep stocking densities. ${ }^{19}$ Difficulties were compounded by weather and disease. In the damp autumns of 1879-1881, millions of sheep died of liver rot, a long-recognized yet poorly understood parasitic disease associated with low-lying and poorly drained pastures. In the bad winter of 1879-1880, many sheep in the Highlands were lost, and others survived only through costly hand feeding. ${ }^{20}$ Meanwhile, the diseases known as braxy and louping ill appeared to increase in prevalence and distribution. Braxy caused numerous sheep to die suddenly in the autumn. Louping ill was a frequently fatal disease of the spring. They occurred particularly in parts of the Scottish Borders and Highlands, and, like liver rot, were associated with particular tracts of land. Climate, soils, vegetation, the lie of the land and tick parasites were all implicated. ${ }^{21}$ These challenges highlighted a tension inherent in sheep farming: breeds renowned for their hardiness and thought to be perfectly adapted to their local environments turned out to be vulnerable to the conditions in which they lived. While supposedly easy to manage, their health was actually rather difficult to maintain.

Sheep disease and death contributed to a deepening depression in British agriculture, which lasted until the First World War. The costs inflicted attracted the attention of several agricultural societies.

\footnotetext{
${ }^{18}$ Reid and Kemp (1871), Usher (1875), Archibald (1880), Hart (1956), Carlyle (1979).

${ }^{19}$ Latham (1883).

${ }^{20}$ Archibald (1880), Reinhard (1957) pp. 220-1, Symon (1959) pp. 192-3, Carlyle (1979).

21 'Second Report' (1883).
} 
The most prominent were the HAS and its English equivalent, the Royal Agricultural Society of England (RASE). These had thousands of members, and were headed by aristocratic landowners and breeders of valuable pedigree stock. Founded at a time when universities and the state had little to do with agriculture, they provided crucial leadership in agricultural research, education, and the dissemination of knowledge and practice. They published journals, ran essay competitions, offered consultancy services to members, and appointed committees of enquiry into agricultural problems of the day. ${ }^{22}$ During the 1880 s, diseased sheep began to feature more prominently in their activities. These animals also attracted the attention of the Duke of Northumberland, one of Britain's wealthiest landowners, who owned vast tracts of diseased land on the Scottish borders.

As shown in Table 3.1, these parties dominated British research on diseased sheep during the late nineteenth century. ${ }^{23}$ They initiated, coordinated and sponsored research, and appointed renowned experts or society consultants to conduct it. They discussed findings in their meetings and published them in their journals. When, in 1901, the government's Board of Agriculture (BA) agreed to appoint a Committee of Enquiry into braxy and louping ill, it was at the behest of these parties, and in response to their promise to provide facilities and expenses. ${ }^{24}$ Most of these enquiries were directed towards braxy and louping ill. The findings varied considerably, and with the exception of Thomas's work on liver fluke-which identified the mollusc Limnaea truncatula as the intermediate host ${ }^{25}$ - they did not make lasting contributions to science, medicine or agriculture. Nevertheless, their analysis offers important insights into how agricultural research was practised in Britain prior to the rise of state-sponsored, university-based enquiry, and the influence that sheep exerted over it.

The diverse qualifications and positions of the investigators listed in Table 3.1 reveals the broadly distributed nature of expertise in sick sheep in late nineteenth-century Britain. Veterinarians were acknowledged

\footnotetext{
${ }^{22}$ Davidson (1984), Goddard (1998), Brassley (2000), Goddard (2000).

${ }^{23}$ There were also smaller-scale enquiries conducted by local farming organizations such as the Teviotdale Farmers Club, but space does not permit their discussion here.

${ }^{24}$ Board of Agriculture (1900).

${ }^{25}$ Reinhard (1957) pp. $220-7$.
} 


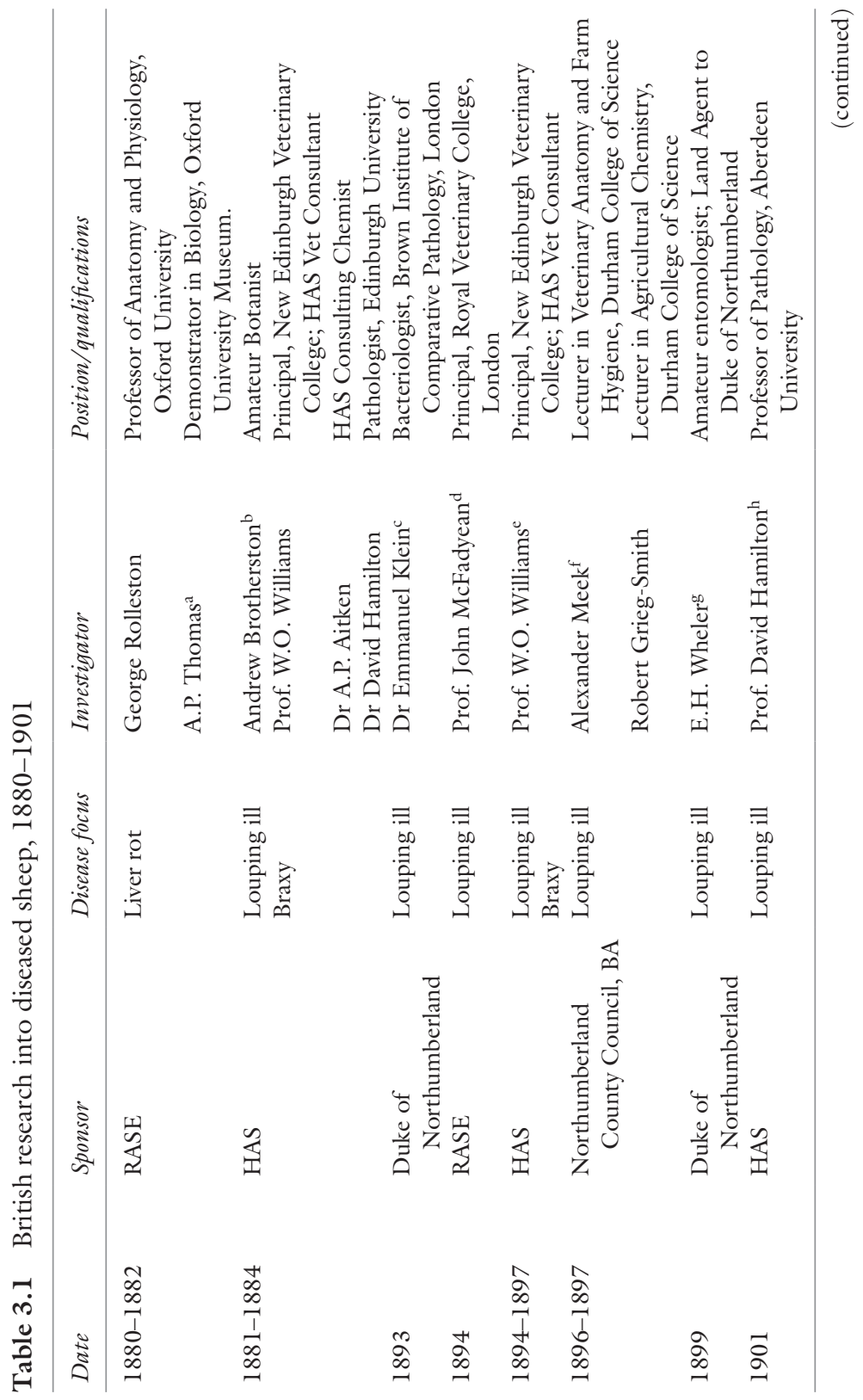




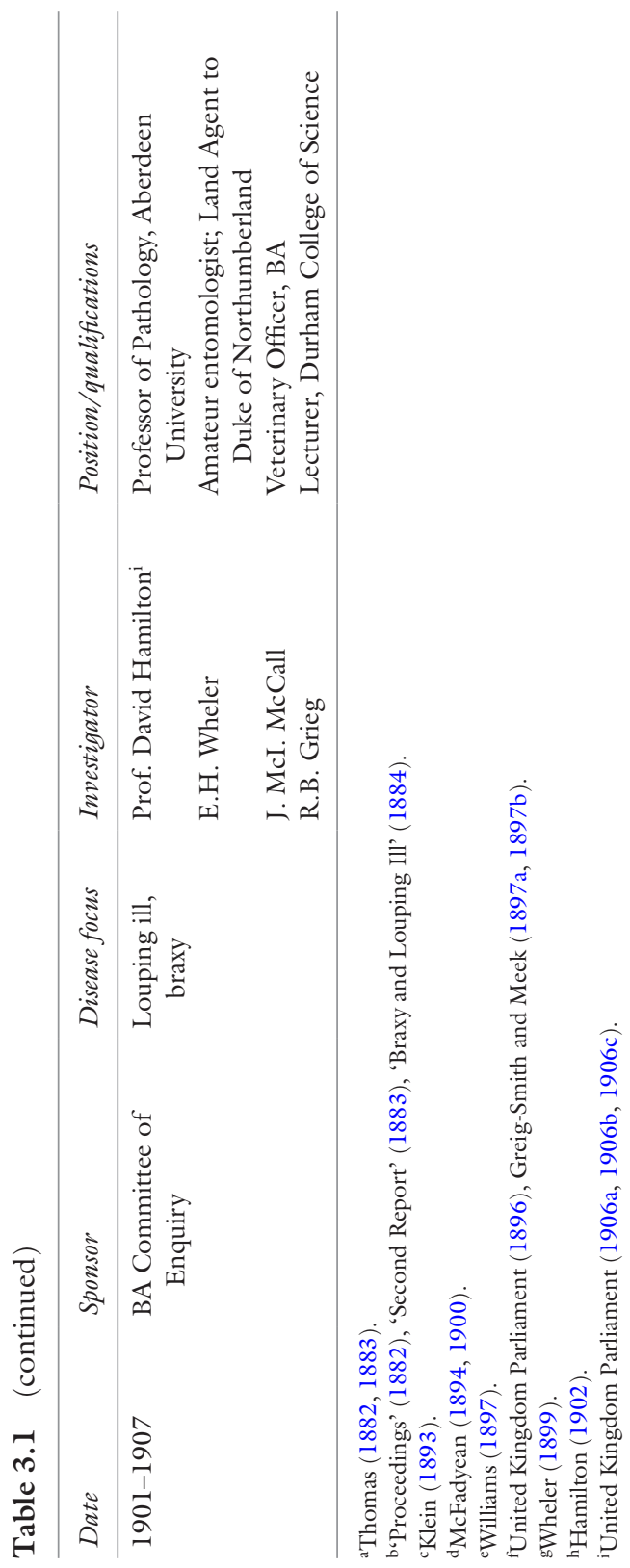


experts, who worked as agricultural society consultants, and helped to make and implement government policy for the control of contagious animal diseases. However, they were not the only ones. Many farmers believed that their shepherds knew more about sick sheep and so summoned vets infrequently to their farms. ${ }^{26}$ They also consulted country medical practitioners about the health of their stock. ${ }^{27}$ Wider medical interest is revealed by commentaries on sheep diseases that appeared in the medical press. ${ }^{28}$ Doctors investigated these diseases in private farmbased research programmes, in their capacities as appointees to government committees of enquiry, and as public health doctors who worked to prevent animal challenges to human health. ${ }^{29}$ For example, Dr David Hamilton, the key medical participant in braxy and louping ill research, studied sick sheep during hiking holidays in the Highlands. Reportedly 'on the news of an animal dying from braxy he would take to the hill with the shepherds'. He also conducted enquiries into cattle diseases on behalf of the HAS. ${ }^{30}$

Other expert participants in sheep disease investigations included amateur natural historians, and professional life scientists who occupied recently established university posts in biology and agriculture. Their involvement reflected the importance that the farmers who sponsored and promoted these investigations placed on the environment as a contributor to sheep disease. Farming discussions frequently referred to the health implications of geology, soil, vegetation, season, temperature, wind direction, the lie of the land, and the presence of parasitic ticks and flukes that fed off sheep bodies and whose existence was, in turn, shaped by the characteristics of the soil, season and vegetation. ${ }^{31}$

Similar factors were commonly invoked in discussions of human health, particularly within colonial contexts. ${ }^{32}$ However, they had special

\footnotetext{
${ }^{26}$ Armatage (1894).

${ }^{27}$ Tellor (1879).

${ }^{28}$ For example: Hutchinson (1877), 'The Report of the Departmental Committee'
} (1906), 'The Pathology of Louping-Ill and Braxy' (1906). Hutchinson's interest in sheep helps to explain his keenness to promote the zoo-based investigation of disease under the Pathological Society of London, as described in Chapter 2.

${ }^{29}$ Hutchinson (1877), Worboys (1991), Bresalier et al. (2015).

30 'Obituary' (1909).

31 'Proceedings' (1882), 'Second Report' (1883).

${ }^{32}$ Harrison (2000), Rupke (2000). 
resonance for sheep because of how farmers perceived them, as essentially defined by their environments. Farmers attributed the existence of so many different sheep breeds to the influence of different locations, such that 'every description of soil and climate has its own variety of sheep'. As outlined above, they celebrated and valued sheep adaptations to environments, and witnessed on a daily basis how these environments both shaped and were shaped by sheep bodies and habits. ${ }^{33}$ They perceived both bodies and environments to be highly variable: even within a single farm, no two stretches of grazing were alike, while in any flock, sheep exhibited a range of characters and physical needs. ${ }^{34}$ The farmers and shepherds who knew their lands and flocks therefore had privileged insights into sheep health. These provided a crucial stimulus, a jumpingoff point and an ongoing guide to scientists' investigations. While farmers did not write scientific reports, their disease experiences and opinions were frequently reported within them, and they were often thanked by scientists for providing information, advice, sheep bodies and facilities for investigation. ${ }^{35}$

Owing to their different backgrounds, experiences and skills, investigators viewed sheep in different ways and adopted different approaches to their diseases. ${ }^{36}$ Brotherston, the amateur botanist, approached sheep as grazing animals, and sought to identify the type and health of the grasses they consumed. ${ }^{37}$ Zoologist A.P. Thomas, and amateur entomologist E.G. Wheler, saw sheep as hosts for parasites whose life cycles, habits and environments they studied. ${ }^{38}$ Doctors, veterinarians and the Durham College team approached sheep as harbourers of microbes and used bacteriological methods to try to determine the identities

\footnotetext{
${ }^{33}$ Reid and Kemp (1871), Scott (1886).

${ }^{34} \mathrm{Scott}(1886)$.

${ }^{35}$ For example: 'Proceedings' (1882), 'Second Report' (1883), McFadyean (1894), Williams (1897), United Kingdom Parliament (1906a). The authority awarded to farmers' opinions, and their input into scientific investigations, was characteristic of livestock disease enquiries in this period. Woods (2009).

${ }^{36} \mathrm{Mol}$ and Law describe an analogous process in reference to the 2001 foot-and-mouth disease epidemic, whereby sheep were defined differently by different actors, and in sometimes incompatible ways. They refer to its various framings as 'sheep multiple.' Law and Mol (2008).

${ }^{37}$ Brotherston (1882).

${ }^{38}$ Thomas (1882), Wheler (1899).
} 
and routes of microbial transmission. ${ }^{39}$ These men could not agree on whether the exciting cause of louping ill was a fungus, a bacterium or a tick-borne poison, or on its relationships to exposure, weather, nutrition and parasitic burdens. However, all concurred with their farming sponsors in viewing diseased sheep as essentially problems of place.

Some of these investigators emphasized the direct impact of farmed environments on sheep constitutions, others their indirect effects on the exciting agents of disease. They also noted how sheep had shaped the very environments that were undermining their health. Their grazing behaviours had damaged the fertility and composition of pastures, which their bodies had contaminated by shedding ticks and bacteria. Therefore to improve sheep health it was necessary to protect bodies from environments, and environments from bodies. Some experts recommended burning, draining or top-dressing pastures, supplementary feeding for sheep, and grazing cattle alongside them to distribute manure and discourage the rank grasses that supported ticks. ${ }^{40}$ Others called for the isolation of newly sick and dead sheep to prevent ticks and bacteria from leaving their bodies. They attempted to protect sheep from environmental threats by dipping them in chemicals, moving them between pastures, drenching them with borax powers, or force-feeding them sulphur with oats. ${ }^{41}$ These interventions impacted on the lived experiences of sheep and disrupted their abilities to 'go at large over their walk'. While occasionally farmers reported good effects, evidence suggests that the demographics of sheep disease did not change significantly during the later nineteenth century.

As problems of place, it made sense to investigate sick sheep within the environments that were so integral to their health. Researchers therefore based themselves on working farms, which they identified via agricultural society connections or by posting advertisements in newspapers. With the permission of their hosts-most frequently the Duke of Northumberland and his tenant farmers - they transformed fields into test sites, and farm buildings into hospital wards, isolation pens, post-mortem rooms and

\footnotetext{
${ }^{39}$ Klein (1893), McFadyean (1894), Greig-Smith and Meek (1897a), United Kingdom Parliament (1906a).

${ }^{40}$ Brotherston (1882), 'Second Report' (1883), Williams (1897).

41 'Second Report' (1883), Klein (1893), McFadyean (1894), Williams (1897), GriegSmith and Meek (1897a, 1897b), Wheler (1899).
} 
experimental laboratories. ${ }^{42}$ The result was a curious hybrid, a place for producing meat, wool and scientific knowledge, which cannot be described adequately using standard historical categories of the 'field', 'laboratory' or even the 'field station' or 'model farm'. ${ }^{43}$ There, sheep became subjects of commercialized production and medicalized investigation at the same time, their identities continually in flux.

Published reports reveal that in the investigation of braxy and louping ill, most investigators built individualized relationships with their sheep subjects, presenting each as a 'case' or 'experiment' whose features they described in turn. ${ }^{44}$ This convention persisted even when several sheep were subjected to the same interventions. It can be explained partly by the very variable responses of sheep bodies to disease and experiment. While farmers attributed such variability to the differences between sheep, investigators suspected that the 'disease' under investigation was in fact several diseases. ${ }^{45}$ In their efforts to disentangle and make sense of diseased sheep, they fashioned them into patients, pathological specimens and experimental material. They kept sheep patients in individual pens and monitored their individual signs and symptoms of disease. Through natural death or purposeful killing, they then transformed these patients into pathological specimens, observing their organs, tissues and bodily fluids with the naked eye and under the microscope. They also tried to culture bacteria from parts of sheep bodies, and to reproduce disease by injecting bacteria and bodily fluids into other healthy sheep, which functioned as experimental animals. To elucidate the contributions of plant fungus and ticks to sheep diseases, investigators experimented on farmed sheep, muzzling some to prevent grazing, and covering others in substances to repel ticks. Untouched sheep functioned as experimental controls. All were monitored and the state of their health compared. ${ }^{46}$

These activities informed other scientific work that was performed in geographically distant laboratories, stables and post-mortem rooms,

\footnotetext{
${ }^{42}$ Klein (1893), Williams (1897), United Kingdom Parliament (1906a).

${ }^{43}$ DeBont (2015), Kohler and Vetter (2016). For a contemporary analysis of the farm as a scientific site, see Henke (2000).

${ }^{44}$ For example: McFadyean (1894), United Kingdom Parliament (1906a).

45 'Proceedings' (1882), McFadyean (1894).

46 'Proceedings' (1882), Klein (1893), McFadyean (1894), Greig-Smith and Meek (1897b), Williams (1897) pp. 282-7, Wheler (1899) pp. 641-4, United Kingdom Parliament (1906a).
} 
where investigators continued to refashion and probe the relationships between live sheep, dead sheep, parasites and microorganisms, which they transported from farms by road and rail. Sheep thereby connected rural farms and urban sites of scientific enquiry, and refashioned the activities of both. ${ }^{47}$ Just as farms became laboratories, so laboratories became farms, dedicated to nurturing sheep bacteria and ticks through their life cycles-bacteria on nutrient media, and ticks in glass tubes that contained sand and damp moss. Scientists observed the appearance and behaviour of these organisms. Then, by exposure or injection, they inserted them into the bodies of experimental sheep and other animals that stood in for them-rabbits, guinea pigs, calves and occasionally monkeys. The findings informed their actions on returning to the field. ${ }^{48}$

It was not only the geographies but also the economies of science and agriculture that were closely intertwined. Farmers contributed to the costs of scientific enquiries via their subscriptions to agricultural societies and by making special donations. ${ }^{49}$ They supplied labour for scientific investigations, and sheep subjects. To maintain these sheep, scientists purchased fodder, litter and the services of attendants, and paid the costs of carriage. When investigations were completed, sheep that had not been dismembered were-like the dead zoo animals examined in Chapter 2-transformed into commercial objects. As knackers' meat and wool, their sale helped to offset the costs of their purchase and maintenance. ${ }^{50}$ As a culture medium for bacteria, their bodies also contributed to the development of an oral drench, which Hamilton trialled on farms and then sold as a preventive against louping ill and braxy. Farmers were enthusiastic purchasers, perhaps because the method resembled a folk remedy for louping ill, whereby sheep were drenched with the dung of pigs fed on pasture that was covered with sheep manure. ${ }^{51}$ Illness

\footnotetext{
${ }^{47}$ Latour (1983).

48 'Proceedings' (1882), Klein (1893), McFadyean (1894), Greig-Smith and Meek (1897b), Williams (1897) pp. 282-7, Wheler (1899) pp. 641-4, United Kingdom Parliament (1906a).

${ }^{49}$ The HAS's 1881-1884 enquiry cost $£ 400$. Half of this sum was raised by subscription from farmers in the affected districts. 'Meeting, Board of Directors' (1882) p. 9.

${ }^{50}$ Williams (1897) pp. 282-7, Wheler (1899) pp. 641-4, Hamilton (1902), 'Louping Ill and Braxy' (1906).

${ }^{51}$ Board of Agriculture (1906). Hamilton conceded that there could be a scientific explanation for the reported success of this folk remedy. Hamilton (1909) pp. 475-6.
} 
prevented Hamilton from performing a statistical analysis of the effects of the drench, and all data was lost on his death in 1909. However, subsequent trials suggested that he had considerably overstated its benefits, and its use was discontinued. ${ }^{52}$

In the course of these investigations, diseased sheep were refashioned not only physically but also conceptually, as investigators first used knowledge of other similar diseases to try to make sense of them, and then used the new knowledge created to make deductions about other puzzling health problems. Their investigations comprised another strand of the historically overlooked form of 'comparative pathology' described in Chapter 2. Pre-dating and continuing alongside the germ theoryinspired version, which probed the bacterial connections between human and animal diseases, ${ }^{53}$ this field drew strength from existing ideas about the biological similarities between species, which allowed insights to be drawn through analogical reasoning. ${ }^{54}$ Brotherston's suspicion that plant fungi were implicated in louping ill was informed by the analogy of ergot, a fungus found on rye, whose consumption was known to cause premature labour and nervous symptoms in humans and livestock. ${ }^{55} \mathrm{In}$ highlighting the role of ticks, Wheler drew analogies with the North American disease known as Texas fever, whose 1893 investigation by Smith and Kilbourne had established the principle of tick-borne infection. ${ }^{56}$ Williams, Klein and the Durham College team drew analogies with anthrax, a high-profile and widely investigated disease that spread via spores insheep fleeces and the soil. ${ }^{57}$

By contrast, Hamilton claimed that louping ill and braxy exhibited an entirely new pathological phenomenon. He believed that the bacteria which caused them were always present in sheep's intestines but only became pathogenic under certain conditions. By applying this finding to other diseases, he hoped to shed 'new light on the pathology of many of the contagious and infectious diseases of man and lower animals' ${ }^{58}$

\footnotetext{
${ }^{52}$ Board of Agriculture (1908-12).

${ }^{53}$ Wilkinson (1992), Hardy (2003).

${ }^{54}$ This method found particular application within the field of comparative anatomy, as described in Chapter 2.

${ }^{55}$ Armatage (1872), Plowright (1886) p. 197.

${ }^{56}$ Wheler (1899), Farley (1989).

57 'Proceedings' (1882), Klein (1893), Greig-Smith and Meek (1897b).

${ }^{58}$ United Kingdom Parliament (1906a) p. 5.
} 
As possible analogies, he suggested several puzzling human diseases such as chlorosis, pernicious anaemia, a type of tetanus, chorea, epilepsy, insanity and cirrhosis of the liver. ${ }^{59}$ Although later disproved, this idea generated medical interest at the time,${ }^{60}$ especially from longstanding advocate of comparative medicine, Clifford Allbutt, regius professor of physic at Cambridge University, who lauded the connections that Hamilton had drawn between animal and human health. ${ }^{61}$

Sheep were not passive participants in these enquiries. Their positioning at the hub of the research network that their diseases had brought into existence, and the primacy of farmers in that network, granted them many opportunities to influence its activities. Their tendency to fall sick in certain seasons, locations and circumstances informed farmers' encounters with, and understandings of them, which in turn shaped the work of scientists who relied on farmers to supply information, sheep bodies, funds and facilities for disease investigations. ${ }^{62}$ Sheep also shaped investigations directly through their unremarked upon compliance with, and more obvious resistance to, scientists' efforts to make sense of them. This resistance took various forms. Sometimes their failure to fall sick in the anticipated times and places limited the course of scientific enquiry. Aitken and Hamilton had to abandon their 1881 enquiries on the Isle of Skye because only one diseased sheep could be found. McFadyean was disappointed to locate only 15 sheep during his 1894 visit to Northumberland, while Hamilton had to extend the duration of his BA enquiry by several years owing to the unpredictability of sheep sickness. ${ }^{63}$ Sheep parasites proved equally unpredictable scientific subjects. In 1897, Williams blamed recent improvements in pasture for the non-appearance of ticks on a farm he had selected for experiment. ${ }^{64}$ The implications for Thomas's work on liver rot were more serious. He set out to test suspicions that a certain snail was the intermediate host, but in 1881 it was nowhere to be found, even in places where it had existed

\footnotetext{
${ }^{59}$ Hamilton (1906).

60 'The Report of the Departmental Committee' (1906), 'The Pathology of Louping-ill and Braxy' (1906), Richardson (1909).

${ }^{61}$ Allbutt (1906).

${ }^{62}$ United Kingdom Parliament (1906a) pp. 5-12, 31-61.

63 'Proceedings' (1882), McFadyean (1894), United Kingdom Parliament (1906a).

${ }^{64}$ Williams (1897) pp. 282-7.
} 
the previous year. In forcing Thomas to delay his enquiries until 1882, the snail enabled his rival in Leipzig, Rudolph Leuckart, to claim priority for its discovery. ${ }^{65}$

Sheep could disrupt scientists' plans in other ways. Those suffering from braxy often died suddenly, preventing investigation of their signs and symptoms in life. ${ }^{66}$ Efforts to define louping ill were impeded by the great variety of symptoms and pathologies exhibited by sheep sufferers. ${ }^{67}$ Hamilton eventually identified a whole class of sheep diseases whose symptoms, pathologies and causes overlapped with louping ill and braxy, and affected other species as well. ${ }^{68}$ Diseased sheep often resisted the application of bacteriological techniques. Their bodily fluids would not transmit louping ill when conveyed orally or by injection. Nor would sick sheep infect healthy ones that were stabled with them. ${ }^{69}$ Responses to tick infestation were equally ambiguous: some sick sheep exhibited few ticks; healthy ones were often covered in them. ${ }^{70}$ Williams brought ticks from the Highlands to Edinburgh in order to determine how experimental sheep responded to them, but tick and sheep failed to bond. ${ }^{71}$ Likewise, in Durham, Meek and Grieg-Smith carefully nurtured ticks through their life stages in the laboratory, only to find that their larvae formed just a brief attachment to the noses of experimental mice. ${ }^{72}$ In these various ways, the non-human participants in sheep diseases influenced human attempts to make sense of them.

\subsection{Research Reconfigurations}

As outlined above, most investigations into diseased sheep in the period 1880-1901 were sponsored and directed by agriculturalists, whose concern for the agricultural economy, and vision of diseased sheep as environmental products and shapers, led them to appoint experts working

\footnotetext{
${ }^{65}$ Thomas (1882), Reinhard (1957) pp. 220-7.

66 'Proceedings' (1882) p. 46.

67 'Proceedings' (1882), McFadyean (1894).

${ }^{68}$ United Kingdom Parliament (1906c).

${ }^{69}$ United Kingdom Parliament (1906a, 1906b).

70 'Second Report' (1883) pp. 176-7.

${ }^{71}$ Williams (1897) pp. 282-7.

${ }^{72}$ Greig-Smith and Meek (1897a) p. 257.
} 
across various fields of enquiry, whose methods and approaches were influenced by them and their sheep. Subsequently, however, the research network was reconfigured, as were its underpinning ideas, approaches and implications for sheep. This was the result of a gradual and uneven process of change that began with the 1889 formation of a government BA, and accelerated following the passage of the 1909 Development Act, which awarded substantial state funding for agricultural research and distributed it via a Development Commission (DC).

Formed in response to the agricultural depression, the BA and DC largely displaced the agricultural societies as sponsors of sheep disease research. Together with the concurrent expansion of civic universities, the BA's support for agricultural education encouraged the institutionalization, specialization and professionalization of sciences allied to agriculture, including the overlapping fields of agricultural zoology, economic biology (which promoted the practical applications of biology to agriculture) and entomology (the study of mites, ticks and insects). ${ }^{73}$ The BA also provided funds for committees to enquire into the sheep diseases, scab (1903) and abortion (1905-1913), and supported additional investigations by its Veterinary Department. In 1908 it funded the expansion of the department's small, run-down laboratory into an 8-acre facility containing laboratories, post-mortem rooms, accommodation for livestock and experimental animals, and an experimental sheep dip. ${ }^{74}$ Further expansion was supported by the DC, which channelled funds into selected fields of enquiry pursued within nominated institutions. Agricultural zoology and animal pathology were key beneficiaries. $^{75}$

Table 3.2 outlines the main investigations into sheep diseases that took place during the first two decades of the twentieth century. It reveals that state funding permitted more extensive, longer-term investigations into a wider range of sheep diseases than before. The vets, John McFadyean and his son-in-law, Stewart Stockman, mounted an extensive, collaborative programme of research ${ }^{76}$ that went beyond braxy

\footnotetext{
${ }^{73}$ Kraft (2004), Clark (2009).

${ }^{74}$ Stockman (1907), United Kingdom Parliament. Annual Reports (1910) p. 15. For more on the shifting modes and politics of state-sponsored veterinary research in this period, see Woods (2013).

${ }^{75}$ Anon (1967) pp. 62-8, Olby (1991).

${ }^{76}$ United Kingdom Parliament (1920) pp. 70-95.
} 


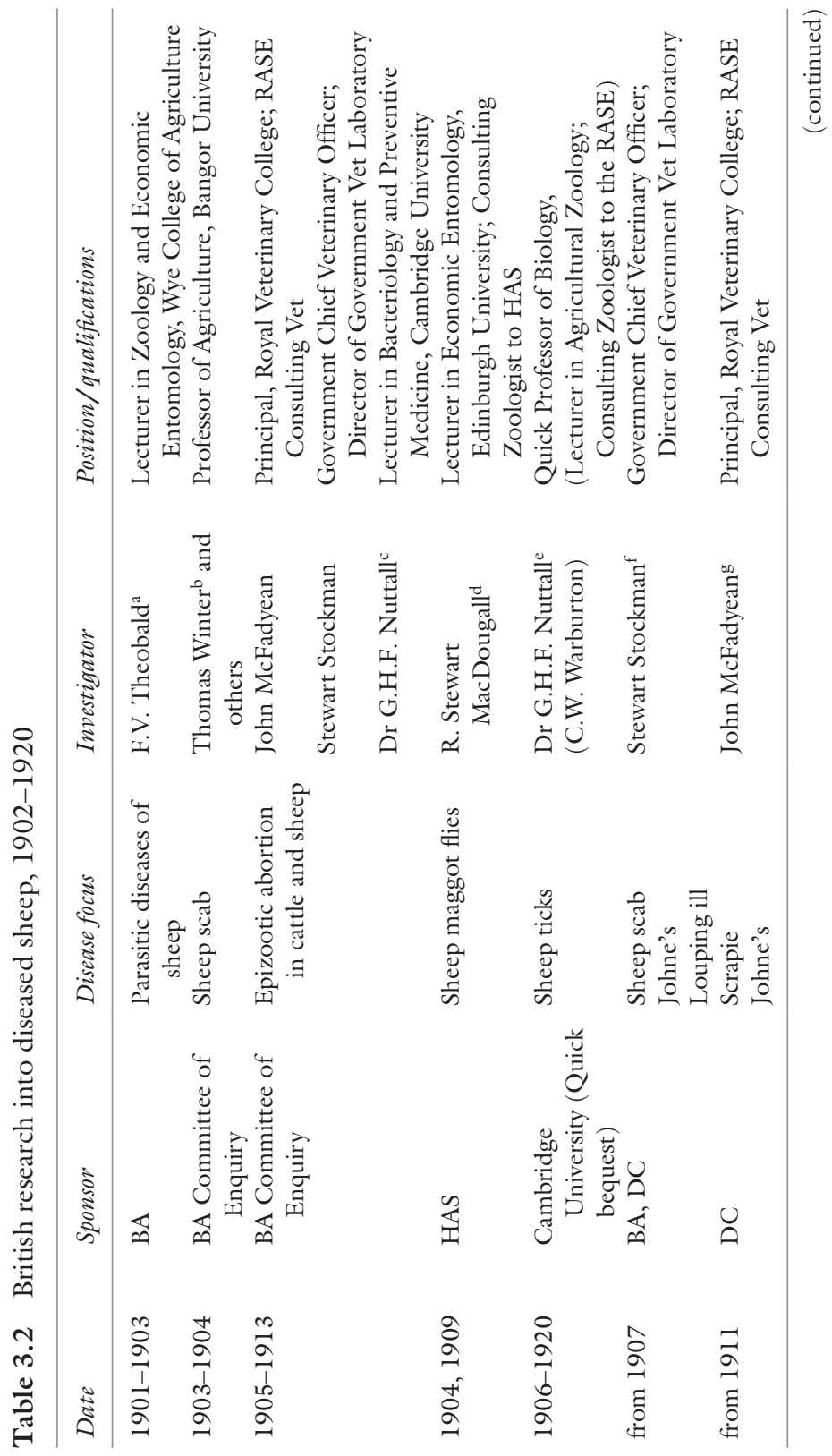


90 A. WOODS

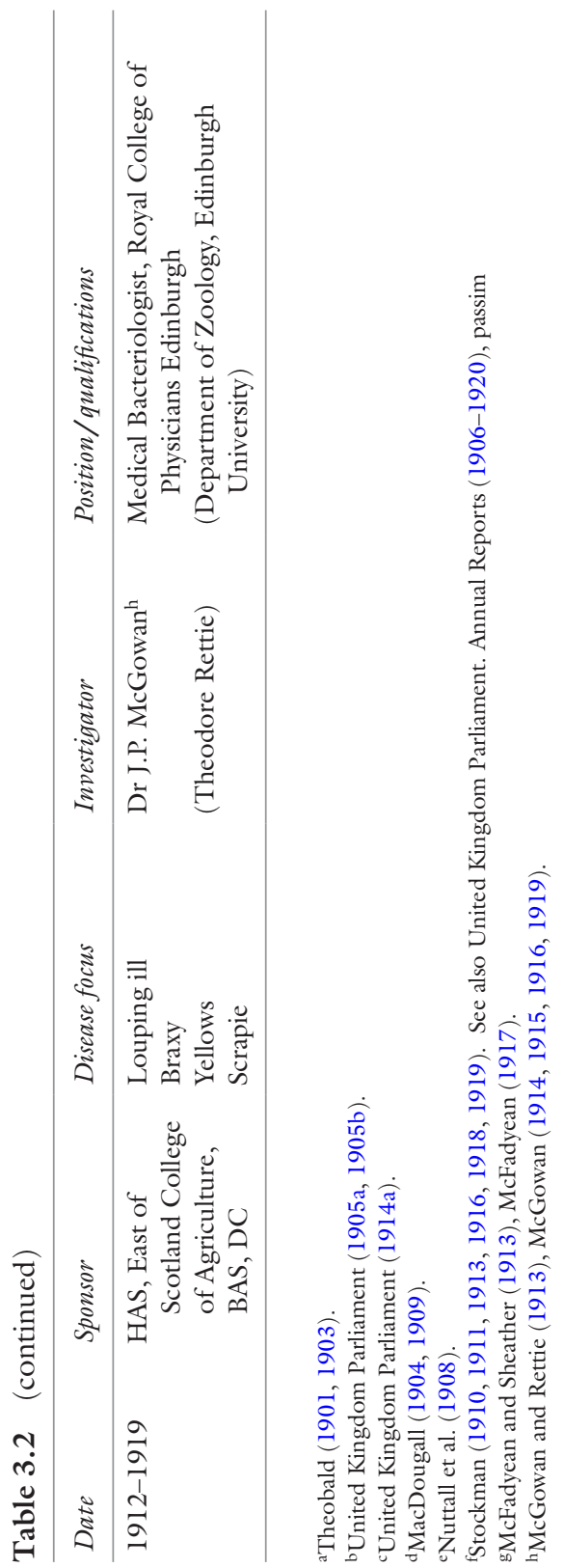


and louping ill to include sheep scab, ${ }^{77}$ scrapie $^{78}$ and Johne's disease. ${ }^{79}$ Zoologists and entomologists such as F.V. Theobald, C. Warburton and Dr G.H.F. Nuttall (who lectured in bacteriology and preventive medicine before benefiting from the Quick bequest, which funded his post and research as professor of biology at Cambridge University ${ }^{80}$ ) incorporated the ticks, mites and flies responsible for sheep diseases into wider studies of insects relevant to human, animal and plant health. ${ }^{81}$ Further stimulus for their investigations was provided by the emergence, and promotion by the government's Colonial Office of tropical medicine as a specialism dedicated to diseases spread by insect vectors. ${ }^{82}$ British agriculture and tropical medicine therefore shaped each other in ways that merit further historical elucidation. ${ }^{83}$

State-funded researchers possessed much more autonomy than under the previous, agriculturally-dominated regime. Those who were appointed to BA committees of enquiry were allowed to pursue their own lines of investigation into the diseases selected. Those funded by the DC were awarded considerable 'latitude and elasticity' owing to its perceived difficulty in predicting whether research would have the desired practical impacts. ${ }^{84}$ Many researchers maintained close links with agriculture-for example, by providing consultancy services to societies. However, farmers were no longer their prime audiences or suppliers of information. Their creation of societies such as the Association of Economic Biologists, and their foundation of, and publication within, new scientific journals (e.g. Parasitology, Journal of Agricultural Science, Journal of Economic Biology and Journal of Comparative Pathology and

${ }^{77}$ This was understood to be an irritating and highly contagious skin disease caused by a mite. It impacted severely on sheep welfare, wool and meat production, and was notifiable by law.

${ }^{78}$ An obscure, chronic disease that caused wasting and itching.

${ }^{79} \mathrm{~A}$ chronic wasting disease that occasionally affected sheep but mainly cattle.

${ }^{80}$ Graham-Smith and Keilin (1939).

${ }^{81}$ F.V. Theobald was best known for his description of the 21,000 mosquitos gathered by colonial officials at the request of Colonial Secretary Joseph Chamberlain (Theobald (1901-1910)). In collaboration with Warburton and others, Nuttall wrote the definitive manual on ticks. He also conducted investigations into tick-borne diseases of dogs and livestock in the tropics. Clark (2009), Cox (2009).

${ }^{82}$ Worboys (1976), Farley (1989), Brown (2005).

${ }^{83}$ Kraft (2004), Clark (2009).

${ }^{84}$ United Kingdom Parliament (1912-1913a) p. 8. 
Therapentics) illustrate the emergence of professionalized, self-referential scientific communities for whom diseased sheep were not simply agricultural problems but also problems for science, whose solution promised personal and professional advancement.

Not all experts benefited equally from the new research landscape. Those located outside formal research institutions, such as amateur natural historians, were unable to tap DC funds and consequently became distanced from professional science. ${ }^{85}$ Those working outside the areas prioritized by the DC, such as medical men working in medical institutions, could only compete for the small quantity of funds left over after nominated institutions had received their share. ${ }^{86}$ The state's involvement therefore encouraged the separation of amateur from professional science, and of fields dedicated to animals and animal health (veterinary medicine and zoology) from those primarily concerned with humans. ${ }^{87}$

English agricultural societies were generally content to cede their leadership of agricultural research to scientists and the state. However, the Scottish societies, which had done the most to promote diseased sheep research, were unhappy that virtually all of the institutions supported by the DC were in England. The DC defended itself on the grounds that only institutions with a strong track record merited research funding, and that 'what may be called pure research is not a local matter, and consequently the proper division of effort is not by geographical districts'. ${ }^{88}$ This did not satisfy the Scots, whose perceptions of sheep and their diseases were deeply localized. They also fumed over the BA's reluctance to cede control of livestock disease research to a new Board of Agriculture for Scotland (BAS, established in 1911). ${ }^{89}$ The HAS and the East of Scotland College of Agriculture therefore decided to sponsor (with limited support from the BAS and the DC) their own enquiries into diseased sheep. Their appointment of the Scottish medical bacteriologist and farmer's son, Dr J.P. McGowan, to conduct these enquiries reveals continuing faith in medical expertise in sick sheep.

\footnotetext{
${ }^{85}$ Johnson (2016).

86'Advances from the Development Fund' (1913).

${ }^{87} \mathrm{Kraft}$ (2004).

${ }^{88}$ United Kingdom Parliament (1912-1913a) p. 7.

${ }^{89}$ Board of Agriculture (1912).
} 
Working with the Edinburgh zoologist, Theodore Rettie, McGowan began in 1912 to investigate louping ill, which he saw as analogous to poliomyelitis in humans. He moved on to braxy (which he attributed to the same bacteria as louping ill), a type of jaundice he thought analogous to human cholera, and the obscure disease known as scrapie which was reportedly increasing in prevalence. His enquiries proceeded along established lines. Continuing to view diseased sheep as problems of place, he considered the local influences of season, pasture, weather patterns and landscape on their bodies. Working at the Edinburgh Lunacy Board's farm in Linlithgowshire, on private farms and in his laboratory at the Royal College of Physicians, Edinburgh, he examined sheep clinically in life and by post-mortem after death, and conducted bacteriological experiments on their bodily tissues and fluids. Sheep both facilitated and impeded his enquiries in the ways outlined above. Landowners and farmers provided crucial assistance in obtaining information regarding the occurrence of the disease, in procuring diseased animals for observation, and in other ways'. ${ }^{90}$ His recommendations focused on the improvement of pasture, and the management of sheep grazing and breeding. ${ }^{91}$

In contrast, this approach was rarely adopted by the beneficiaries of BA and DC funding. Departing from the received view of sick sheep as products and shapers of unhealthy environments, they focused instead on sheep relationships with other infected and infective bodies. Believing that environments were unimportant, they sidelined the farmers and natural historians who knew about them, ignored the local specificities of vegetation, topography and sheep, and considered climate only in its effects on bacteria and parasites. They pursued their enquiries by extracting sheep and their infective agents, physically and conceptually from their specific farms of origin, and refashioning them within laboratories into generic subjects of investigation, which they hoped would produce universal knowledge of disease more readily than the locally specific sheep of the field.

Zoologists and entomologists investigated different stages in the life cycles of parasitic mites and ticks by 'farming' them in glass tubes and incubators, and working out how changes in temperature and moisture

\footnotetext{
${ }^{90}$ McGowan (1914).

${ }^{91}$ McGowan $(1915,1916)$.
} 
influenced their development. ${ }^{92}$ Within their separate institutions, vets replicated some of these enquiries and also worked on bacteria. They continued to fashion diseased sheep into patients, pathological specimens and experimental subjects in efforts to determine the identities and effects of infective agents, and how sheep bodies influenced their capacity to grow, reproduce and transmit. Drawing on his prior experience as principal veterinary officer to the Transvaal, Stockman devised new analogies for louping ill: the tick-borne protozoal cattle disease known as East Coast Fever, which ravaged Southern Africa in the early years of the century, and a milder equivalent known as redwater, which he had identified in Britain. ${ }^{93}$ Recommendations focused on preventing the transmission of infection by controlling sheep movements between farms, removing them from tick-infested pastures and submerging them periodically in chemical dips-which occasionally killed sheep in addition to their parasites. ${ }^{94}$

These shifts in the ideas and locations of sheep disease research followed wider, well-documented trends in science and medicine. The period witnessed an uneven move from general environmental understandings to specific models of disease causation, which directed attention towards infectious agents invading susceptible bodies and away from the spaces they inhabited. ${ }^{95}$ Concurrently, the scientific drive for greater control over natural phenomena encouraged the formation of laboratories and experimental stations, and downgraded the field as a site for constructing credible scientific knowledge. ${ }^{96}$ These developments did not impact automatically on investigations into diseased sheep; rather, their effects were mediated by the changing capacity of sheep and their farmers to shape the course of scientific investigation.

As shown earlier, the late nineteenth-century farmers who sponsored and participated in sheep disease research (and by extension, the sheep whose habits and bodies moulded their views) had encouraged scientists to view diseased sheep as problems of place, and to study

\footnotetext{
${ }^{92}$ Theobald (1903), United Kingdom Parliament (1905b) pp. 23-36, Nuttall et al. (1908).

${ }^{93}$ Stockman (1911b), Stockman (1916), Cranefield (1991).

${ }^{94}$ Stockman (1910), McFadyean and Sheather (1913), Stockman and Berry (1913), Stockman (1916), McFadyean (1917), Stockman (1918), Stockman (1919).

${ }^{95}$ Worboys (2009).

${ }^{96}$ Kohler (2002).
} 
them in their local environments with the aid of experts like themselves who understood these animals and landscapes. However, the shift from agricultural to state funding loosened the personal, geographical and economic ties that linked the commercial production of sheep to the scientific production of knowledge about their diseases. No longer answerable to agricultural sponsors or tied to their visions of disease, scientists were free to follow emerging scientific trends. The facilities supplied by state-funded scientific institutions meant that they no longer depended on farmers and their sheep for insights and bodies. They relied on labour supplied by technicians, not farm workers, and attempted to create their own research material by the deliberate infection of experimental sheep, or by fashioning other animal species into experimental models that could stand in for them.

There is little evidence to suggest that these changes in how diseased sheep were conceptualized and investigated brought more substantial benefits to sheep, science and agriculture than the former, agriculturally dominated regime. Investigators remained puzzled by the aetiologies of braxy and louping ill, sheep scab remained prevalent, and scrapie proved impossible to unravel. It was not until the interwar period that British scientists began to make headway against some of these diseases and to develop successful methods of managing them in the field. ${ }^{97}$ One possible reason for this lack of progress is that sheep did not wholly support scientists' conceptions of them as infecting and infective agents, or comply with efforts to transform them from locally specific to generic laboratory sheep. Stockman tried in vain to locate in ticks and sheep blood cells the microscopic protozoon that he believed-from the analogies of East Coast Fever and redwater - to be the cause of louping ill. Nor could he induce disease by inoculating healthy sheep with the bodily fluids of sick ones, or with emulsions made from up to a thousand tick eggs. Consequently, he was unable to determine experimentally whether particular sheep possessed immunity to infection. Their resistance to his experimental manipulations forced him to return literally to the field, where he transformed experimental sheep into farmed sheep and vice versa, by collecting spontaneously sick sheep for his experiments, and depositing experimental sheep to test their immunity to natural infection..$^{98}$

\footnotetext{
${ }^{97}$ Anon (1925), Anon (1965) pp. 62-8, Angus (1990).

${ }^{98}$ Stockman (1916), Stockman (1918). The cause of louping ill was later identified as a tick-borne virus.
} 
Sheep also thwarted McFadyean's laboratory-based efforts to transmit scrapie experimentally and culture its causal agent, but farmers' secrecy concerning the presence of disease made it difficult for him to gather naturally infected sheep from farms. ${ }^{99}$ Sheep abortion, too, posed challenges to veterinary researchers. They found it difficult to maintain causal bacteria in vitro, but sheep would only accept the infection when pregnant, and their physiologically restricted breeding seasons confined investigations to particular times of year. ${ }^{100}$ Zoologists likewise relied on visits to the field to acquire new parasites for their investigations, while Stockman was forced to gather ticks from the bodies of dying farmed sheep because the ticks he nurtured in his laboratory would not reveal through experiment whether they contained the infective agent of louping ill. ${ }^{101}$

These investigations proved to scientists that it was not so easy to ignore the local circumstances, sheep and infective agents of the field in favour of those nurtured and manipulated within the laboratory. Unexpectedly, inhabitants of the laboratory's generic spaces sometimes proved more unpredictable than those found on locally specific farms. This may explain why Stockman embarked on efforts to recreate the natural conditions of the field in his laboratory. In one experiment he tried to mimic farm-based encounters between sheep and scab mites by tying wool and scurf from infected sheep into the fleeces of healthy ones. ${ }^{102}$ $\mathrm{He}$ also fashioned pill boxes into cages for female mites and tied them to the skin of sheep to allow them to feed. ${ }^{103}$ To test the tick's ability to acquire and transmit infection, he farmed them within his laboratory and actively encouraged them, at different stages in their life cycles, to fix onto and feed off sheep as they would in the field. He enclosed sheep ears and scrotums in cotton bags in order to capture the ticks for examination when they dropped off after eating their fill. ${ }^{104}$ Following

\footnotetext{
${ }^{99}$ McFadyean (1917), United Kingdom Parliament (1920) pp. 77-9. The cause of scrapie remained contentious for decades and was eventually identified as a prion, a highly unconventional agent.

${ }^{100}$ Skirrow (2006).

${ }^{101}$ Stockman (1916) p. 259.

${ }^{102}$ Stockman (1910).

${ }^{103}$ Stockman and Berry (1913).

${ }^{104}$ Stockman (1911).
} 
Latour, historians would typically interpret such activities as attempts to build authority for the laboratory, by inverting the power relationships between humans and disease agents that operated in the field. ${ }^{105}$ In this context, however, when sheep and their infective agents had already demonstrated their capacity within the laboratory to subvert the power of humans, Stockman's work could be regarded as an acknowledgement of their agency, and the need to find space for its operation in the laboratory. ${ }^{106}$ In these ways, sheep, their parasites and microorganisms made a difference to research practices, and maintained the permeability of emerging boundaries between the laboratory and the field.

\subsection{Watertight COMPartments}

The final section of this chapter takes a more intimate look at some of the disciplinary politics of diseased sheep research in early twentiethcentury Britain. As shown above, the growth of state funding in this period led to the narrowing of earlier eclectic perspectives on sick sheep, promoted the research of vets and zoologists over that of doctors and natural historians, and distanced practical farmers from the scientific study of sheep. For veterinary researchers, Stewart Stockman and John McFadyean, these changes did not go far enough. Keen to achieve the status of prime experts in animal health, they sought to capture sick sheep for themselves by awarding them a new role as vehicles for veterinary professional ambitions.

These vets were not the first to try to advance the profession's status. Earlier efforts, stretching back to the 1820s, had been impeded by internecine strife within the profession, its competitors' demonstrable effectiveness in the management and investigation of animal disease, and its inferior social and scientific status relative to human medicine. ${ }^{107}$ However, John McFadyean had made some headway in attempts to create a distinctive veterinary research tradition. He had trained also as a doctor in order to gain a more advanced scientific education than that provided to vets, and proceeded to apply his skills in work performed at the Royal Veterinary College's Research Institute in Animal Pathology,

\footnotetext{
${ }^{105}$ Latour (1983).

${ }^{106}$ This interpretation is supported by Law and Mol (2008).

${ }^{107}$ Worboys (1991), Woods (2007), Woods and Matthews (2010).
} 
which was founded in 1892 with the support of the RASE. In 1888 he established the Journal of Comparative Pathology and Therapentics (JCPT), which he used as a mouthpiece for his opinions and to publicize the results of his research. ${ }^{108}$ His papers on louping ill, which appeared in JCPT in 1894 and 1900, were highly critical of other researchers. He condemned Dr Klein's 'failure to recognise that the name [louping ill] covers a variety of diseases' and declared the conclusions of Edinburgh vet, Professor Williams to be 'quite untrustworthy'. ${ }^{109} \mathrm{He}$ also claimed that other investigators' views about the causes of louping ill were simply 'theories' based on 'scraps of evidence', whereas what diseased sheep really required was 'painstaking reinvestigation at the hands of a competent pathologist'. 110

By the early twentieth century, McFadyean and his son-in-law Stockman-who was appointed government chief veterinary officer in 1905-dominated the veterinary research scene. They ran laboratories that benefited considerably from public funding, and were knighted for their services in 1905 and 1913, respectively. However, the future was far from secure. In 1912, BA discussions about veterinary research generated proposals to divert funds and resources from Stockman's and McFadyean's institutions to Cambridge University, where medical and agricultural researchers were keen to investigate intransigent livestock diseases that Stockman had been unable to elucidate. A merger between The Royal Veterinary College, the medically run Brown Institute of Comparative Pathology, and London University was mooted, and the BAS was agitating for its own programme of animal disease research in Scotland. ${ }^{111}$ One of the ways in which Stockman and McFadyean sought to counter these threats and elevate the status of their profession was through the physical and rhetorical manipulation of sick sheep.

\footnotetext{
${ }^{108}$ Pattison (1981).
}

${ }^{109}$ McFadyean (1894), McFadyean (1900). McFadyean's antipathy to Williams was partly political. As principal of the Dick College of Veterinary Medicine, Edinburgh, Williams had been asked by the governors to resign his post in 1893 . He left to create a New Edinburgh Veterinary College, and took most of the students, museum specimens and library with him. McFadyean entered the Dick in 1874, and eventually married the daughter of Thomas Walley, who had worked under Williams and succeeded him as principal. Warwick and MacDonald (2003).

${ }^{110} \mathrm{McFadyean}$ (1900).

${ }^{111}$ Board of Agriculture (1912), Hall (1913), 'Animal Diseases' (1914), United Kingdom Parliament (1914b) p. 441. 
One of their strategies was to assert ownership of as many sheep diseases as possible, and to use Stockman's annual reports to Parliament and McFadyean's JCPT to publicize their investigations in progress. This enabled them to claim authority over sheep through long association with them, and to deny others the resources they needed to investigate sheep diseases. When Dr Frederick Twort, medical bacteriologist and director of the Brown Institute of Comparative Pathology in London, sought DC funds to continue his work on culturing the bacterium of Johne's disease and developing a vaccine, McFadyean engineered a rejection on the grounds that research was already under way in his laboratory. ${ }^{112}$ When, in 1915, medical bacteriologist J.P. McGowan published the results of his investigations into scrapie, McFadyean dismissed them because the enquiry had only lasted 18 months, whereas his own research had begun seven years previously. ${ }^{113}$

Another veterinary strategy was to emphasize not only the duration but also the nature of their relationships with sick sheep. While they made no claims to an affective bond with sheep, the men argued repeatedly that their clinical experience, pathological knowledge, and epidemiological investigations had enabled them to develop intimate understandings of sheep bodies, sheep parasites, and, crucially, of the interactions between them. By making a distinction between their relationships with sheep and those built by zoologists, who were primarily interested in sheep parasites, they sought to differentiate and promote veterinary expertise.

This strategy is evident in veterinary responses to sheep scab, a disease caused by a highly contagious infective mite that lived in the skin and induced severe itching, loss of wool and loss of condition. In the late nineteenth century, scab was eradicated from New Zealand and Australia with the aid of regular, compulsory dipping of sheep in chemicals that killed the mite. In response to British agriculturalists' call for similar measures, in 1903 the government established a committee to consider the merits of dipping in relation to the practical conditions of sheep farming and the life history of the scab mite. ${ }^{114}$ Composed of experts drawn from medicine, chemistry, biology, agriculture and veterinary

112 'Reports on Applications' (1911), Ingram and Twort (1913).

${ }^{113}$ McGowan (1914), McFadyean (1917), McFadyean (1918).

114 'Mr Long' (1898), Wallace (1900), Kirkwood (1986), Fisher (1998). 
medicine, it oversaw dipping experiments conducted by Professor Winter, professor of agriculture at Bangor University. Expert witnesses included the zoologists F.V. Theobald and C. Warburton, who had performed independent investigations of the mite's life cycle and habits (Table 3.2). ${ }^{115}$ On the strength of the committee's recommendations, in 1907 the government made annual sheep dipping compulsory, but this had little impact on the incidence or distribution of scab. ${ }^{116}$

Stockman believed that the foundations of this policy were insecure. The circumstances of the outbreaks that he had investigated-as required under law-led him to query 'the generally accepted facts regarding the epizootiology of scab', which derived from entomologists' 'somewhat academic' studies of parasite life cycles. He claimed that what was really needed was 'the study of the various habits of a parasite under actual conditions'. ${ }^{117}$ McFadyean concurred. He claimed that Winter had conducted too few experiments and failed to take into account the sheep's clinical condition when assessing the effects of dipping. ${ }^{118}$ Such criticisms implied that these researchers' relationships with diseased sheep were too superficial to generate authoritative knowledge.

Stockman made similar criticisms of zoologists' investigations into the ticks that were implicated in louping ill. Arguing that 'the study of the life-history of a parasite by entomologists is often limited to the cycle of its development', which 'does not by any means complete our knowledge of them', he called for observations of 'their habits, which, from the economic point of view, are of as much interest as their developmental cycle'. ${ }^{119}$ By 'habits' he meant how parasites lived in relation to sheep, and acted to cause disease in them. While he believed that entomologists had their uses, particularly when working under veterinary direction, ${ }^{120}$ the study of parasite habits was, for him, a pathological not a zoological problem, which could only be solved by veterinarians. When, in 1911, the Edinburgh zoologist, Theodore Rettie, bid for DC funds to investigate louping ill, Stockman objected 'on principle' because Rettie had 'no medical qualifications and proposed to do a path-

\footnotetext{
${ }^{115}$ United Kingdom Parliament (1905a, 1905b).

${ }^{116}$ Anon (1965) pp. 164-8.

${ }^{117}$ United Kingdom Parliament. Annual Reports (1910) p. 11.

${ }^{118}$ Editorial (1904) pp. 233-40.

${ }^{119}$ Stockman (1911b).

${ }^{120}$ United Kingdom Parliament (1912-1913b) p. 41.
} 
ological experiment'. He was overruled by the BA's zoological advisor, $S$. MacDougall, on the grounds that sheep with louping ill were probably infected by ticks, which were Rettie's 'special province' as a zoologist. ${ }^{121}$ Stockman retaliated by adding louping ill to the list of diseases that he was investigating. He also spoke out against Cambridge biology professor G.H.F. Nuttall, who claimed that a drug known as tryptanblue might be effective in the treatment of certain tick-borne animal diseases. Stockman objected because Nuttall had failed to conduct extensive trials on animals in the field. ${ }^{22}$

Medical bacteriologists were similarly accused of focusing on disease agents in isolation from sheep, instead of devoting attention to what they did 'in the body under different conditions'. ${ }^{123}$ McGowan's research on scrapie, which implicated a parasite in the muscles known as sarcocystis, was a case in point. Although his own research on the disease had been unproductive, McFadyean rejected McGowan's conclusions as 'unproved and improbable', and his recommendations as based on inadequate experience. ${ }^{124}$ Having spent considerable time consulting farmers and studying scrapie in the field, McGowan resisted this attempt to portray him as an abstract, laboratory-bound, out-of-touch theoretician. He accused McFadyean of dogmatism, a lack of evidence, and a failure to understand farming terminology and practice. ${ }^{125}$ McFadyean maintained the attack, accusing McGowan of 'meagre' evidence and of failing to investigate the transmission of disease between sheep. As a parting shot, he claimed that McGowan would only do harm by delaying investigations along 'the only lines likely to yield satisfactory results' ${ }^{126}$ — by which he meant, veterinary lines.

Veterinary attempts to set distance between their lengthy, meaningful interspecies relationships, and zoologists' and medical researchers' abstract focus on singular disease agents, were highly rhetorical. While there were some differences in their methods, objectives and relationships with research subjects, there was also considerable overlap. Stockman,

\footnotetext{
121 'Reports on Applications' (1911).

${ }^{122}$ Nuttall and Hadwen (1909a), Nuttall and Hadwen (1909b), Stockman (1909).

${ }^{123}$ United Kingdom Parliament (1912-1913b) p.41.

${ }^{124}$ McFadyean (1917) p. 112.

${ }^{125}$ McGowan (1918).

${ }^{126}$ McFadyean (1918) p. 299.
} 
too, studied parasites in the laboratory, in isolation from sheep hosts, and with the aid of 'artificial' incubation. ${ }^{127}$ Nuttall and McGowan built close relationships with sheep as well as their parasites and bacteria, and sought to determine the relationships between them. ${ }^{128}$ Investigations aimed at controlling disease were not the special province of veterinarians. McGowan was answerable to his agricultural patrons, who wished to promote sheep farming, while Theobald was a founder of the Association of Economic Biologists, which promoted the value of economic biology to practical agriculture. ${ }^{129}$ Nuttall and Warburton studied the economic and medical significance of ticks as well as their life cycles, and Nuttall often commented on the economic importance of parasites and their relationship to disease in humans and animals. ${ }^{130}$

It was no coincidence that the people whom Stockman and McFadyean criticized or sought to exclude from diseased sheep research were investigating the same diseases as them, in association with institutions that stood to gain from the diversion of power and funds away from their own-the BAS, the Brown Institute and Cambridge University. Ultimately, this diversion did not occur. The Royal Veterinary College remained autonomous and in London; power to conduct disease research remained vested in the BA in London; and the foundation of a chair in comparative pathology at Cambridge University did not materialize until 1926, in isolation from veterinary research and teaching. However, these outcomes occurred not because of, but in spite of the relationships that Stockman and McFadyean built with their sheep. In fact, the sheep's role as carrier of professional ambitions was not particularly successful because it did not deter non-veterinarians from studying their diseases, or change wider perceptions of those researchers' abilities relative to those of vets. Parasitic causes of sheep diseases continued to attract attention from scientists who identified increasingly as 'parasitologists', ${ }^{131}$ and McGowan continued to work on livestock diseases for Scottish agriculturalists and subsequently at an agricultural research institution, the Rowett Institute in Aberdeen. ${ }^{132}$

\footnotetext{
${ }^{127}$ United Kingdom Parliament. Annual Reports (1912-1913) pp. 22-9.

${ }^{128}$ Nuttall and Hadwen (1909a, 1909b), McGowan (1914).

${ }^{129}$ Collinge (1907), Kraft (2004).

${ }^{130}$ Nuttall et al. (1908), Nuttall (1914), Nuttall (1918), Kraft (2004).

${ }^{131}$ Worboys (1976), Cox (2009).

${ }^{132}$ Smith (1999).
} 
Nevertheless, Stockman's and McFadyean's attempts to establish hierarchical relationships between disciplines on the basis of the relationships that their researchers built with sick sheep had some lasting effects. Although, for some years to come, diseased sheep and other livestock remained shared objects of concern for investigators in veterinary medicine, human medicine and the life sciences, the investigations that were performed on them were not shared but proceeded along parallel tracks. The veterinary fashioning of sheep into vehicles for their professional ambitions prevented the development of integrated research campaigns and constructive cross-disciplinary conversations. If the state funding of agricultural research had already fractured investigations coordinated by agricultural societies into disciplinary compartments, then it was the vets who made those compartments 'watertight'l33 through their antipathy to other researchers. Well beyond the period examined in this chapter, any institutional or state attempts to promote non-veterinary perspectives on sick livestock prompted a fierce backlash from veterinary leaders, who continued to assert their profession's unique possession of knowledge arising from their special relationships with animals. ${ }^{134}$

\subsection{Conclusion}

In outlining the structures, knowledge-practices and social configurations of agricultural research in Britain around the turn of the twentieth century, this chapter has highlighted the transition from scientifically eclectic, small-scale investigations that were funded and coordinated by farmers for farmers, to more substantial, state-funded enquiries that were performed by autonomous scientists. In treating the research of both periods symmetrically, and demonstrating the capacity of sheep to make a difference to scientific investigations, it highlights the inadequacy of existing historical accounts, which confine their attention to human actors and publicly funded research programmes.

Against a backdrop of rising international competition and falling meat and wool prices, it was the sheep's tendency to fall ill and die that prompted late nineteenth-century agricultural societies to commission enquiries into the causes and management of their diseases.

133 'Watertight compartments' was an actors' term that referred specifically to the separation of veterinary from human medicine. Allbutt (1906), McFadyean (1923) p. 253.

${ }^{134}$ Editorial (1931), Angus (1990), Woods (2004). 
Subsequently, as contributors to the deepening depression in agriculture, their continuing deaths encouraged the state to assume some responsibility for this activity. Throughout, sheep exerted influence over how and where research was practised, and by whom. In the earlier period, the symptoms they suffered, and the geography and seasonality of their diseases, reinforced agricultural sponsors' perceptions of them as products of place, and led to their positioning at the hub of research networks populated by experts in their bodies and environments. Their tendency to fall ill at particular times and in particular places shaped the questions that these experts asked of them, and led to their investigation on farms. State-funded researchers in the early twentieth century paid less heed to the farmed environment and conducted narrower, discipline-specific, laboratory-based enquiries that were underpinned by their different perceptions of sheep as hosts and transmitters of infection. However, their non-human subjects forced them to return intermittently to the field. Throughout, the sheep's variable responses to both disease and scientific investigations generated a host of conflicting claims about their diseases. Their acknowledged importance as research subjects also encouraged ambitious veterinarians to enrol them in a campaign for professional advancement, which drew strength from the lengthy and intimate relationships that vets claimed to have developed with them.

In the course of these activities, sheep built relationships between diverse human and non-human actors including: scientific experts and the state; the microbes, parasites and environments implicated in sheep diseases; the human and animal victims of analogous diseases that helped to shed light on sheep; and the multiple species of experimental animals that acted as sheep proxies. Through these relationships, sheep were awarded new roles as patients, pathological specimens, experimental material, culture media, victims and shapers of their environments, subjects of field trials, hosts and transmitters of infection, food for parasites, points of comparison with other species, and commercial products. Made and remade in the course of scientific enquiries, the sheep's identity was in a constant state of flux. Their lived experiences also changed. As scientific subjects, sheep underwent clinical monitoring and treatment, feeding trials, dipping, experimental inoculations, parasitic infections, and premature, purposeful deaths. This had ramifications for farmed sheep, which were treated by dipping, drenching, dosing, isolation, managed grazing and restricted breeding in efforts to promote their health. 
In these ways, sheep and scientific research were co-constituted. Two aspects of this process merit further note. First is the power of sheep to make a difference to research structures, practices and participants. This is an important issue for animal studies scholars because while they accept that, in theory, animals gain the capacity to inadvertently change history by entering into relationships with humans, it is the historically contingent nature of those relationships that determines the scope and effects of their influence. ${ }^{135}$ This analysis has shown that in enquiries run by farmers for farmers, sheep made a considerable difference to how, where and by whom research was conducted. However, when state funding freed scientists from their obligations to agricultural sponsors, and endowed new laboratories for the pursuit of scientific enquiry, scientists sought to make sheep and their infective agents answerable to them. Their efforts were not entirely successful. As we have seen, sheep retained some of their power to frustrate and to require scientists to return to the field. There is little evidence to suggest that (in this period at least) this mode of investigation was more scientifically productive than that which it replaced. Nevertheless, the extraction of sheep-and scientific enquiries-from their local farmed environments did reduce their power to shape science, and indicates how the rise of modern, institutionalized, publicly funded research regimes elevated the authority of scientists at the expense of animals and their owners.

Second, this study reveals the capacity of sick sheep to shape the relationships between different fields of scientific enquiry. While historians of science and medicine have tended to view sheep as veterinary subjects and relegate them to the field of veterinary history, this chapter has shown that, in the late nineteenth century, sick sheep also attracted attention from-and therefore merit insertion within the histories of human medicine, natural history and zoology, which came together to create the multifaceted domain of 'agricultural science'. It has also demonstrated how the position of sheep at the intersection of these fields changed during the early twentieth century as structural changes in university research and teaching, the growth and distribution of public funds for agricultural research, and the changing knowledge-practices of sheep investigations promoted professional zoology at the expense of amateur natural history, and veterinary research at the expense of

\footnotetext{
${ }^{135}$ Law and Mol (2008), Pearson and Weismantel (2010), Nance (2015) p. 3.
} 
medicine. Ambitious vets then worked to consolidate these boundaries and elevate their own perspectives in a bid for recognition as supreme experts in sheep health. This historical study therefore offers important insights into disciplinary boundaries in the making, the ways in which sick sheep first brought together, and then contributed to the drawing apart of, human medicine, veterinary medicine and the life sciences. Its findings suggest that when deciding what constitutes the history of 'medicine', 'veterinary medicine' or 'the life sciences', historians need to seek out these fields' historical identities and relationships, which the history of animals - as key points of connection and disconnection-has a unique capacity to illuminate.

The historical forging of disciplinary identities and relationships is also an important issue for the present-day agenda known as $\mathrm{OH}$. As described in Chapter 6, since 2000, OH has gained increasing international prominence in health research, policy and discourse. Its advocates argue that because many of today's most pressing health problems lie at the interface of human, animal and environmental health, they can only be managed effectively by breaking down traditional disciplinary silos and developing more collaborative ways of working. They often turn to history in attempts to build authority for this approach. ${ }^{136}$ However, in the belief that its benefits are universal and self-evident, they tend to pluck historical figures out of their contexts and celebrate their $\mathrm{OH}$ achievements without considering the circumstances that made it possible or desirable for individuals to work in this way. Their celebration of John McFadyean as a figurehead for $\mathrm{OH}$ when he actually contributed to the early twentieth-century demise of this way of working flags up the problems associated with this approach to history. ${ }^{137}$

Late nineteenth-century research on sick sheep could, in retrospect, be described as $\mathrm{OH}$ because it cut across and drew connections between different fields of enquiry. As we have seen, this approach derived from the broadly distributed nature of expertise in sick sheep, and the leading role of agricultural societies, which selected from this pool of experts, and directed enquiries with agricultural ends in mind. Its subsequent fracturing was the result of institutional, funding and disciplinary changes, and the manoeuvrings of McFadyean and Stockman, which

\footnotetext{
${ }^{136}$ For example: Zinsstag et al. (2011).

${ }^{137}$ For example: Day (2008), Monath et al. (2010).
} 
produced structures, career paths and disciplinary rivalries that privileged discipline-specific over problem-based approaches. Practical farmers, medical researchers and natural historians were marginalized, and vets grew more interested in exerting authority over zoologists than in working with them towards the improvement of sheep health. Sheep ceased to be subjects of $\mathrm{OH}$ not because they ceased to be pressing and costly problems for agriculture but because scientific investigators no longer had the will or the capacity to address them as such. If $\mathrm{OH}$ today is to move from 'rhetoric to reality', it is these sorts of dynamics and contexts that its advocates need to engage with, rather than simply urging scientists repeatedly to recognize the logic of a $\mathrm{OH}$ approach. ${ }^{138}$

\section{BIBLIOGRAPHY}

“Advances from the Development Fund." 1913. British National Archives: D $2 / 8$.

Allbutt, Clifford. "Comparative Medicine." The Times, June 5, 1906: 9.

Allen, David. The Naturalist in Britain: A Social History. London: Penguin, 1976.

Angus, K. A History of the Animal Diseases Research Association. Edinburgh: ADRA, 1990.

"Animal Diseases - Demand for Research." The Times, May 4, 1914: 4.

Anon. "Animal Pathology and Physiology." The Lancet 206 (1925): 343.

Anon. Animal Health, a Centenary 1865-1965. London: HMSO, 1965.

Anon. "The Central Veterinary Laboratory, Weybridge, 1917-1967." Veterinary Record 81 (1967): 62-8.

Archibald, David. "On the Cheviot Breed of Sheep." Transactions of the Highland and Agricultural Society VII (1880): 110-22.

Armatage, George. "On Abortion and Premature Labour in Mares, Cows, and Ewes." Transactions of the Highland and Agricultural Society IV (1872): 173-9.

Armatage, George. The Sheep: Its Varieties and Management in Health and Disease. London: F. Warne \& Co, 1894.

Armstrong, Phillip. Sheep. London: Reaktion, 2016.

Benson, Etienne. "Animal Writes: Historiography, Disciplinarity, and the Animal Trace." In Making Animal Meaning, edited by L. Kalof and G.M. Montgomery, 3-16. East Lansing, MI: Michigan State University Press, 2011.

${ }^{138}$ Okello et al. (2011), Hueston et al. (2013). 
Board of Agriculture. "Correspondence - Braxy and Louping Ill." 1900-01. British National Archives: MAF 35/246.

Board of Agriculture. "Correspondence - Departmental Committee, Interim Report. Louping Ill and Braxy." 1906-12. British National Archives: MAF $35 / 247$.

Board of Agriculture. "Correspondence - Veterinary Education and Research." 1912. British National Archives: MAF 33/47.

Brassley, Paul. "Agricultural Research in Britain, 1850-1914: Failure, Success and Development." Annals of Science 52 (1995): 465-80.

Brassley, Paul. "Agricultural Science and Education." In The Agrarian History of England and Wales, volume 7, edited by E.J.T. Collins and J. Thirsk, 594649. Cambridge: Cambridge University Press, 2000.

"Braxy and Louping Ill: Report by Committee." Transactions of the Highland and Agricultural Society XVI (1884): 300-3.

Bresalier, Michael, Angela Cassidy and Abigail Woods. "One Health in History." In One Health: The Theory and Practice of Integrated Health Approaches, edited by J. Zinsstag, E. Schelling, D. Waltner-Toews, M. Whittaker and M. Tanner, 1-15. Wallingford: CABI, 2015.

Brotherston, A. "Report on the Flora of Upper Teviotdale in Connection to its Relation to 'Louping Ill' in Sheep." Transactions of the Highland and Agricultural Society XIV (1882): 43-5.

Brown, Karen. "Political Entomology: The Insectile Challenge to Agricultural Development in the Cape Colony, 1895-1910." Journal of Southern African Studies 29 (2003): 529-49.

Brown, Karen. "Tropical Medicine and Animal Diseases: Onderstepoort and the Development of Veterinary Science in South Africa 1908-1950." Journal of Southern African Studies 31 (2005): 513-29.

Brown, Karen. "Poisonous Plants, Pastoral Knowledge and Perceptions of Environmental Change in South Africa, c.1880-1940." Environment and History 13 (2007): 307-32.

Butler, Alan. Sheep. Winchester: O Books, 2006.

Carlyle, W.J. "The Changing Distribution of Breeds of Sheep in Scotland, 17951965." Agricultural History Review 27 (1979): 19-29.

Cassidy, Angela, Rachel Mason Dentinger, Kathryn Schoefert and Abigail Woods. "Animal Roles and Traces in the History of Medicine." In Animal Agents: the Non-Human in the History of Science, edited by Amanda Rees. BJHS Themes 2 (2017): 11-33.

Cittadino, Eugene. "Botany." In The Cambridge History of Science, volume 6: Modern Biological and Earth Sciences, edited by Peter Bowler and John Pickstone, 225-42. Cambridge: Cambridge University Press, 2009.

Clark, John. Bugs and the Victorians. London: Yale University Press, 2009. 
Clayton, N. "'Poorly Co-ordinated Structures for Public Science that Failed us in the Past'? Applying Science to Agriculture: A New Zealand Case Study." Agricultural History 82 (2008): 445-67.

Collinge, W. "The Application of Economic Biology to Agriculture." Journal of Economic Biology 3 (1907): 96-106.

Cox, F.E. "George Henry Falkiner Nuttall and the Origins of Parasitology." Parasitology 136 (2009): 1389-94.

Cranefield, Paul. Science and Empire: East Coast Fever in Rhodesia and the Transvaal. Cambridge: Cambridge University Press, 1991.

Crosby, A. The Columbian Exchange: Biological and Cultural Consequences of 1492. Westport, Conn.: Greenwood Publishing Company, 1972.

Davidson, James. The Royal Highland and Agricultural Society of Scotland, A Short History: 1784-1984. Ingliston: Blackwood Pillans and Wilson, 1984.

Day, M.J. "One Health and the Legacy of John McFadyean." Journal of Comparative Pathology 139 (2008): 151-3.

De Bont, R.F.J. Stations in the Field: A History of Place-based Animal Research, 1870-1930. London: University of Chicago Press, 2015.

Despret, Vinciane. "Sheep Do Have Opinions." In Making Things Public. Atmospheres of Democracy, edited by B. Latour and P. Weibel, 360-70. Cambridge: M.I.T. Press, 2006.

Editorial. "The Prevention and Treatment of Sheep Scab." Journal of Comparative Pathology and Therapeutics 17 (1904): 233-40.

Editorial. "Agricultural Research Council." Veterinary Record 43 (1931): 761-2.

Farley, John. "Parasites and the Germ Theory of Disease." Milbank Quarterly 67 (1989): S1, 50-68.

Fisher, John. "Technical and Institutional Innovation in Nineteenth Century Australian Pastoralism: The Eradication of Psoroptic Mange in Australia." Journal of the Royal Australian Historical Society 84 (1998): 38-55.

Franklin, Sarah. Dolly Mixtures: The Remaking of Genealogy. Durham, NC: Duke University Press, 2007.

Fudge, Erica, "Ruminations 1: The History of Animals' (2006). Accessed February 19, 2017. https://networks.h-net.org/node/16560/ pages/32226/history-animals-erica-fudge.

Goddard, Nicholas. Harvests of Change: The Royal Agricultural Society of England 1838-1988. London: Quiller, 1998.

Goddard, Nicholas. "Agricultural Institutions: Societies, Associations and the Press." In The Agrarian History of England and Wales, volume 7, edited by E.J.T. Collins and J. Thirsk, 650-92. Cambridge: Cambridge University Press, 2000.

Graham-Smith, G.S. and D. Keilin. "George Henry Falkiner Nuttall. 1862-1937." Biographical Memoirs of Fellows of the Royal Society 2 (1939): 493-9. 
Greig-Smith, R. and A. Meek. "Investigation into the Cause of Louping Ill." Veterinarian 70 (1897a): 249-62.

Greig-Smith, R. and A. Meek. "On Louping Ill and its Connection with the Tick." Veterinarian 70 (1897b): 698-709.

Hall, Daniel. "Memo." 1913. British National Archives: D4/91.

Hamilton, D.J. "On Braxy." Transactions of the Highland and Agricultural Society XIV (1902): 314-47.

Hamilton, David. "On the Alimentary Canal as a Source of Contagion." In Studies in Pathology, edited by W. Bulloch, 1-38. Aberdeen: University of Aberdeen, 1906.

Hamilton, D.J. "Evidence to Royal Commission on Vivisection.” British Medical Journal I (1909): 475-6.

Haraway, Donna. When Species Meet. Minneapolis: University of Minnesota Press, 2008.

Hardy, Anne. “Animals, Disease and Man: Making Connections." Perspectives in Biology and Medicine 46 (2003): 200-15.

Harrison, Mark. "Differences of Degree: Representations of India in British Medical Topography, 1820-c.1870." Medical History 44 (2000): S20, 51-69.

Hart, J.F. "The Changing Distribution of Sheep in Britain." Economic Geography 32 (1956): 260-74.

Henke, C. "Making a Place for Science: The Field Trial." Social Studies of Science. 30 (2000): 483-511.

Hueston, W., J. Appert, T. Denny et al. "Assessing Global Adoption of One Health Approaches." Ecohealth 10 (2013): 228-33.

Hutchinson, Jonathan. "A Report on Certain Causes of Death in Ewes During and After Parturition, with Notes on the "Navel-Ill" in Lambs." Transactions of the Obstetrical Society of London 18 (1877): 88-109.

Ingram, G.A. and F.A. Twort. A Monograph on Johne's Disease. London: Bailliere, Tindall and Cox, 1913.

Johnson, K. "The Natural Historian." In A Companion to the History of Science, edited by B. Lightman, 84-96. Chichester: Wiley Blackwell, 2016.

Jones, Susan. Death in a Small Package: A Short History of Anthrax. Baltimore: John Hopkins University Press, 2010.

Kirk, Robert and Edmund Ramsden. "Working Across Species Down on the Farm: Howard S Liddell and the Development of Comparative Psychopathology, c.1923 to 1962." History and Philosophy of the Life Sciences (2017): forthcoming.

Kirkwood, A.C. "History, Biology and Control of Sheep Scab." Parasitology Today 2 (1986): 302-7.

Klein, E. "On the Etiology and Pathology of Louping-ill." Journal of the Royal Agricultural Society of England 4 (1893): 625-36. 
Kohler, R. and J. Vetter. "The Field." In A Companion to the History of Science, edited by B. Lightman, 282-95. Chichester: Wiley Blackwell, 2016.

Kohler, Robert. Landscapes and Labscapes: Exploring the Lab-Field Border in Biology. Chicago: Chicago University Press, 2002.

Kohler, Robert. All Creatures: Naturalists, Collectors, and Biodiversity, 1850-1950. Princeton: Princeton University Press, 2006.

Kraft, Alison. "Pragmatism, Patronage and Politics in English Biology: The Rise and Fall of Economic Biology 1904-1920." Journal of the History of Biology 37 (2004): 213-58.

Latham, Patrick. "The Deterioration of Mountain Pastures and Suggestions for their Improvement." Transactions of the Highland and Agricultural Society XV (1883): 111-30.

Latour, Bruno. "Give Me a Laboratory and I Will Raise the World." In Science Observed: Perspectives on the Social Study of Science, edited by Karin D. KnorrCetina and Michael Mulkay, 141-70. London: Sage, 1983.

Latour, Bruno. The Pasteurization of France. Translated by Alan Sheridan and John Law. London: Harvard University Press, 1988.

Law, John, and Annemarie Mol. "The Actor-Enacted: Cumbrian Sheep in 2001." In Material Agency: Towards a Non-Anthropocentric Approach, edited by Carl Knappett and Lambros Malafouris, 57-77. London: Springer, 2008.

"Louping Ill and Braxy. Account of Committee Expenditure 1906-1912." British National Archives: MAF 35/247.

MacDougall, R.S. "The Sheep Maggot Fly." Transactions of the Highland and Agricultural Society XVI (1904): 128-43.

MacDougall, R.S. "Sheep Maggot and Related Flies, their Classification, Life History and Habits." Transactions of the Highland and Agricultural Society XXI (1909): 135-74.

McGowan, J.P. Investigation into the Disease of Sheep called 'Scrapie." Edinburgh: Blackwood, 1914.

McGowan, J.P. "Braxy." Transactions of the Highland and Agricultural Society XXVII (1915): 54-141.

McGowan, J.P. Louping Ill. Edinburgh: Blackwood, 1916.

McGowan, J.P. "Scrapie." Journal of Comparative Pathology and Therapeutics 31 (1918): 278-90.

McGowan, J.P. "Cholera of the Sheep (Jaundice; Yellows or Yellowses)." The Lancet 194 (1919): 426-9.

McGowan, J.P. and T. Rettie. "Poliomyelitis in Sheep suffering from Loupin' Ill." Journal of Pathology and Bacteriology 18 (1913): 47-51.

McFadyean, John. "Louping-Ill in Sheep." Journal of the Royal Agricultural Society of England 7 (1894): 547-60.

McFadyean, John. "The Aetiology of Louping-Ill." Journal of Comparative Pathology and Therapeutics 13 (1900): 145-54. 
McFadyean, John. "Scrapie." Journal of Comparative Pathology and Therapeutics 30 (1917): 102-31.

McFadyean, John. "Sarcosporidia as the Cause of Scrapie." Journal of Comparative Pathology and Therapentics 31 (1918): 290-9.

McFadyean, John. "Review of the Progress of Veterinary Science in Great Britain during the Past One Hundred Years." Journal of Comparative Pathology and Therapeutics 36 (1923): 243-55.

McFadyean, J. and A.L. Sheather. "Johne's Disease: The Experimental Transmission of the Disease to Cattle, Sheep, and Goats." Journal of Comparative Pathology and Therapentics 26 (1913): 62-94.

Marson, James and Professor Simonds. Report of Experiments as to Vaccination of Sheep, and Influence of Vaccination in Preventing Sheep-pox. London: Her Majesty's Stationary Office, 1864.

"Meeting, Board of Directors." Transactions of the Highland and Agricultural Society XIV (1882): 9.

Melville, Elinor G.K. A Plague of Sheep: Environmental Consequences of the Conquest of Mexico. Cambridge: Cambridge University Press, 1994.

Monath, T.P., L.H. Kahn and B. Kaplan. "Introduction: One Health Perspective." ILAR Journal 51 (2010): 193-8.

"Mr Long and the Sheep Breeders Association." The Times, April 27, 1898: 14.

Nance, Susan. "Introduction." In The Historical Animal, edited by Susan Nance, 1-18. New York: Syracuse University Press, 2015.

Nuttall, G.H.F. “'Tick Paralysis' in Man and Animals.” Parasitology 7 (1914): 95-104.

Nuttall, G.H.F. "The Pathological Effects of Phthirus Pubis." Parasitology 10 (1918): 375-82.

Nuttall, G.H.F. and S. Hadwen. "The Successful Drug Treatment of Canine Piroplasmosis, Together with Observations upon the Effect of Drugs on Piroplasma Canis.” Parasitology 2 (1909a): 156-91, 229-35.

Nuttall, G.H.F., and S. Hadwen. "The Drug Treatment of Piroplasmosis in Cattle." Parasitology 2 (1909b): 236-66.

Nuttall, G.H.F., C. Warburton, W.F. Cooper and L.E. Robinson. Ticks, A Monograph of the Ixodoidea. Part I. Cambridge: Cambridge University Press, 1908.

“Obituary, D.J. Hamilton.” The Lancet 173 (1909): 730-1.

Okello, A., E.P. Gibbs and A. Vandersmissen. "One Health and the Neglected Zoonoses: Turning Rhetoric into Reality." Veterinary Record 169 (2011): 281-5.

Olby, Robert. "Social Imperialism and State Support for Agricultural Research in Edwardian Britain." Annals of Science 48 (1991): 509-26.

Pattison, Iain. John McFadyean: Founder of Modern Veterinary Research. London: JA Allen, 1981. 
Pearson, S.J. and M. Weismantel. "Does 'The Animal' Exist? Toward a Theory of Social Life with Animals." In Beastly Natures: Animals, Humans and the Study of History, edited by Dorothee Brantz, 17-39. London: University of Virginia Press, 2010.

Peden, R. "Sheep Breeding in Colonial Canterbury (New Zealand): A Practical Response to the Challenges of Disease and Economic Change, 1850-1914." In Healing the Herds: Disease, Livestock Economies and the Globalization of Veterinary Medicine, edited by K. Brown and D. Gilfoyle, 215-31. Athens: Ohio University Press, 2010.

Plowright, Charles. "Some Remarks upon Ergot." British Medical Journal 1 (1886): 197.

"Proceedings at General Meetings: Louping Ill and Braxy." Transactions of the Highland and Agricultural Society XIV (1882): 39-46.

Reid, William, and James Kemp. Sheep: Their History, Management, Diseases, and National Value. Edinburgh: Nimmo and Elliot, 1871.

Reinhard, E.G. "Landmarks of Parasitology I. The Discovery of the Life Cycle of the Liver Fluke." Experimental Parasitology 6 (1957): 208-32.

"Reports on Applications for Advances from the Development Fund." 1911. British National Archives: D 2/4.

Richardson, W.G. "Tetanus Occurring after Surgical Operations." British Medical Journal 1 (1909): 948-51.

Ritvo, Harriet. "Counting Sheep in the English Lake District: Rare Breeds, Local Knowledge, and Environmental History." In Beastly Natures: Animals, Humans, and the Study of History, edited by Dorothee Brantz, 264-80. University of Virginia Press, 2010.

Rupke, N. (ed.). Medical Geography in Historical Perspective. London: Wellcome Trust Centre for the History of Medicine at UCL, 2000.

Ryder, M.L. Sheep and Man. London: Gerald Duckworth \& Co, 1983.

Schlich, Thomas and Martina Schlünder. "The Emergence of 'Implant-Pets' and 'Bone-Sheep': Animals as New Biomedical Objects in Orthopedic Surgery (1960s-2010)." History and Philosophy of the Life Sciences 31 (2009): 433-66.

Scott, Charles. The Practice of Sheep-Farming. Edinburgh: T.C. Jack, 1886.

"Second Report by Special Committee on Braxy and Louping Ill." Transactions of the Highland and Agricultural Society XV (1883): 176-201.

Skirrow, M. "John McFadyean and the Centenary of the First Isolation of Campylobacter Species." Clinical Infectious Diseases 43 (2006): 1213-7.

Smith, David. "The Use of 'Team Work' in the Practical Management of Research in the Inter-War Period: John Boyd Orr at the Rowett Research Institute." Minerva 37 (1999): 259-80.

Stark, James. The Making of Modern Anthrax, 1875-1920. London: Pickering and Chatto, 2013. 
Stockman, Stewart. "Permanent Laboratory." October 25, 1907. British National Archives: MAF 35/578.

Stockman, Stewart. "The Treatment of Redwater in Cattle (Bovine Piroplasmosis) with Trypanblue." Journal of Comparative Pathology and Therapeutics 22 (1909): 321-40.

Stockman, Stewart. "Some Points on the Epizootiology of Sheep Scab in Relation to Eradication." Journal of Comparative Pathology and Therapentics 23 (1910): 303-14.

Stockman, Stewart. "Johne's Disease in Sheep." Journal of Comparative Pathology and Therapeutics 24 (1911a): 66-9.

Stockman, Stewart. "The Habits of British Ticks found on Sheep and Cattle." Journal of Comparative Pathology and Therapeutics 24 (1911b): 229-37.

Stockman, Stewart. "Scrapie: An Obscure Disease of Sheep." Journal of Comparative Pathology and Therapentics 26 (1913): 317-27.

Stockman, S. and A.H. Berry. "The Psoroptes Community Ovis." Journal of Comparative Pathology and Therapentics 26 (1913): 45-50.

Stockman, Stewart. "Louping-ill." Journal of Comparative Pathology and Therapeutics 29 (1916): 244-64.

Stockman, Stewart. "Louping-ill." Journal of Comparative Pathology and Therapeutics 31 (1918): 137-93.

Stockman, Stewart. "Louping-Ill: Duration of the Infectivity of the Ticks." Journal of Comparative Pathology and Therapeutics 32 (1919): 283-5.

Symon, J.A. Scottish Farming, Past and Present. Edinburgh: Oliver and Boyd, 1959.

Tellor, Lloyd V. The Diseases of Live Stock and their Most Efficient Remedies. London: Baillière and Co, 1879.

“The Report of the Departmental Committee." The Lancet 168 (1906): 232-3.

"The Pathology of Louping-Ill and Braxy." British Medical Journal 1 (1906): 1472-4.

Theobald, F.V. Diptera, A Monograph of the Culicidae of the World. British Museum: London, 1901-1910.

Theobald, F.V. "The Parasitic Diseases of Sheep." Livestock Journal, November 8, 1901: 576.

Theobald, F.V. "Sheep Scab." Journal of the Land Agent's Society II (1903): 150-66.

Thomas, A.P. "The Rot in Sheep, or the Life-History of the Liver-Fluke." Nature 26 (1882): 606-8.

Thomas, A.P. "The Natural History of the Liver Fluke and the Prevention of Rot." Journal of the Royal Agricultural Society of England xix (1883): 276-305.

United Kingdom Parliament. Third Report of the Commissioners Appointed to Inquire into the Origin and Nature, \&c. of the Cattle Plague; with an Appendix, Vol. XXII:321, Cd.3656. London: The Stationary Office, 1866. 
United Kingdom Parliament. Report on Distribution of Grants for Agricultural Education in Great Britain, 1895-96, Appendix, Vol. LXVII.585, C.8228. London: The Stationary Office, 1896.

United Kingdom Parliament. Report on Wages and Earnings of Agricultural Labourers in United Kingdom, Vol. LXXXII.557, C.346. London: The Stationary Office, 1900.

United Kingdom Parliament. Report of the Departmental Committee Appointed by the Board of Agriculture and Fisheries to Investigate Experimentally and to Report upon Certain Questions Connected with the Dipping and Treatment of Sheep, Vol. XXI:1, Cd. 2258. London: The Stationary Office, $1905 a$.

United Kingdom Parliament. Minutes of Evidence taken before the Departmental Committee Appointed by the Board of Agriculture and Fisheries to Investigate Experimentally and to Report upon Certain Questions Connected with the Dipping and Treatment of Sheep, with Appendices, Vol. XXI:27, Cd. 2259. London: The Stationary Office, 1905b.

United Kingdom Parliament. Report of the Departmental Committee Appointed by the Board of Agriculture to Inquire into the Aetiology, Pathology, and Morbid Anatomy and Other Matters Connected with the Diseases of Sheep known as Louping-ill and Braxy, Part 1. Vol. XXIV:519, Cd. 2932. London: The Stationary Office, 1906a.

United Kingdom Parliament. Report of the Departmental Committee Appointed by the Board of Agriculture to Inquire into the Aetiology, Pathology, and Morbid Anatomy and Other Matters Connected with the Diseases of Sheep known as Louping-ill and Braxy, Part 2. Vol. XXIV:555, Cd. 2933. London: The Stationary Office, 1906b.

United Kingdom Parliament. Report of the Departmental Committee Appointed by the Board of Agriculture to Inquire into the Aetiology, Pathology, and Morbid Anatomy and Other Matters Connected with the Diseases of Sheep known as Louping-ill and Braxy, Part 3. Vol. XXIV:921, Cd. 2934. London: The Stationary Office, 1906c.

United Kingdom Parliament. Development Commission. Second Report of the Development Commissioners, Vol. XVII.837. London: The Stationary Office, 1912-13a.

United Kingdom Parliament. Minutes of Evidence taken before the Departmental Committee Appointed by the President of the Board of Agriculture and Fisheries to Inquire into the Requirements of the Public Services with Regard to Officers Possessing Veterinary Qualifications; with Appendices and Index, Vol. XLVIII:267, Cd.6652. London: The Stationary Office, 1912-13b.

United Kingdom Parliament. Report of the Departmental Committee of the Board of Agriculture Appointed to Enquire into Epizootic Abortion. 
Appendix to part III - Abortion in Sheep, Vol. XII.101, Cd. 7157. London: The Stationary Office, 1914a.

United Kingdom Parliament. Second Report of the Board of Agriculture for Scotland, Vol. XII.897, Cd. 7434. London: The Stationary Office, 1914b.

United Kingdom Parliament. Development Commission. Fourth Report of the Development Commissioners, Vol. XXV.I. London: The Stationary Office, 1916. United Kingdom Parliament. Development Commission. Tenth Report of the Development Commissioners, Vol. XIII.901. London: The Stationary Office, 1920 .

United Kingdom Parliament. Annual Reports of Proceedings under the Diseases of Animals Acts. London: The Stationary Office, 1900-20.

Usher, John. Border Breeds of Sheep. Kelso: J. \& J.H. Rutherfurd, 1875.

Vernon, Keith. "Science for the Farmer? Agricultural Research in England 19091936." Twentieth Century British History 8 (1997): 310-33.

Wall, Rosemary. Bacteriology in Britain, 1880-1939. London: Pickering and Chatto, 2013.

Wallace, Professor. "Scab in Sheep: Suggestions for its Eradication." Transactions of the Highland and Agricultural Society 12 (1900): 117-36.

Warwick, Colin and Alastair Macdonald. "The New Veterinary College, Edinburgh, 1873 to 1904." Veterinary Record 153 (2003): 380-6.

Wheler, E.G. "Louping-Ill and the Grass Ticks." Journal of the Royal Agricultural Society of England 10 (1899): 626-44.

Wilkinson, Lise. Animals and Disease: An Introduction to the History of Comparative Medicine. Cambridge: Cambridge University Press, 1992.

Williams, W.O. "Louping Ill." Transactions of the Highland and Agricultural Society IX (1897): 278-90.

Woods, Abigail. A Manufactured Plague: The History of Foot and Mouth Disease in Britain, 1839-2001. London: Earthscan, 2004.

Woods, Abigail. "'Partnership' in Action: Contagious Abortion and the Governance of Livestock Disease in Britain, 1885-1921." Minerva 47 (2009): 195-217.

Woods, Abigail. "From Practical Men to Scientific Experts: British Veterinary Surgeons and the Development of Government Scientific Expertise, c18781919." History of Science li (2013): 457-80.

Woods, Abigail. "From One Medicine to Two: The Evolving Relationship between Human and Veterinary Medicine in England, 1791-1835." Bulletin of the History of Medicine 91 (2017), 494-523.

Woods, Abigail and Stephen Matthews. "Little, If At All, Removed from the Illiterate Farrier or Cow-Leech': The English Veterinary Surgeon, c.186085, and the Campaign for Veterinary Reform." Medical History 54 (2010): 29-54. 
Woods, Rebecca. "From Colonial Animal to Imperial Edible: Building an Empire of Sheep in New Zealand, ca. 1880-1900." Comparative Studies of South Asia, Africa and the Middle East 35 (2015): 117-36.

Worboys, M. "The Emergence of Tropical Medicine: A Study in the Establishment of a Scientific Specialty." In Perspectives on the Emergence of Scientific Disciplines, edited by Gerard Lemaine et al., 75-98. The Hague: Mouton, 1976.

Worboys, M. "Germ Theories of Disease and British Veterinary Medicine." Medical History 35 (1991): 308-27.

Worboys, M. "Public and Environmental Health." In The Cambridge History of Science, Volume 6: Modern Biological and Earth Sciences, edited by Peter Bowler and John Pickstone, 141-64. Cambridge: Cambridge University Press, 2009.

Zinsstag, J., E. Schelling, D. Waltner-Toews and M. Tannera. "From 'One Medicine' to 'One Health' and Systemic Approaches to Health and Wellbeing." Preventive Veterinary Medicine 101 (2011): 148-56.

Open Access This chapter is licensed under the terms of the Creative Commons Attribution 4.0 International License (http://creativecommons. org/licenses/by/4.0/), which permits use, sharing, adaptation, distribution and reproduction in any medium or format, as long as you give appropriate credit to the original author(s) and the source, provide a link to the Creative Commons license and indicate if changes were made.

The images or other third party material in this chapter are included in the chapter's Creative Commons license, unless indicated otherwise in a credit line to the material. If material is not included in the chapter's Creative Commons license and your intended use is not permitted by statutory regulation or exceeds the permitted use, you will need to obtain permission directly from the copyright holder.

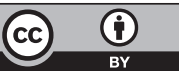

